Joanna Lusek

Muzeum Górnośląskie w Bytomiu

\title{
PRACA PRZYMUSOWA JEŃCÓW WOJENNYCH W BYTOMIU W LATACH II WOJNY ŚWIATOWEJ
}

Streszczenie. W czasie II wojny światowej Górny Śląsk miał wzmocnić niemiecki potencjał gospodarczy poprzez maksymalne zaangażowanie infrastruktury przemysłowej na potrzeby prowadzonych działań zbrojnych. O strategicznym położeniu Bytomia w regionie zadecydowała możliwość szybkiego przekształcenia dotychczasowej produkcji z użytecznej społecznie na potrzeby gospodarki wojennej. Plan ten został zrealizowany $w$ drugiej połowie lat trzydziestych XX w. Górny Śląsk jako ośrodek przemysłu ciężkiego miał konkurować z Zagłębiem Ruhry w Nadrenii Północnej-Westfalii.

Po wybuchu II wojny światowej Bytom znalazł się w rejencji katowickiej. Zakłady przemysłu ciężkiego zlokalizowane w mieście i okolicy (kopalnie, huty i huty współpracujące z nimi) podlegały Zarządowi Górnictwa Bytom-Północ (Bergamt Beuthen-Nord), Zarządowi Górnictwa Bytom-Południe (Bergamt Beuthen-Süd) oraz częściowo Urzędowi Górniczemu Gliwice-Północ (Bergamt Gleiwitz-Nord).

Władze niemieckie szukały skutecznego sposobu realizacji produkcji wojennej. Chodziło o to, aby zminimalizować nakłady inwestycyjne i wykorzystać tanią siłę roboczą. Pozwoliło to na zachowanie ciągłości produkcji w warunkach działań wojennych. W 1940 r. do zakładów przemysłowych wprowadzono więźniów obozów koncentracyjnych, cywilnych robotników przymusowych i jeńców wojennych przetrzymywanych w stalagach Lamsdorf i Teschen. Stalagom podlegało ponad 2500 komand roboczych, z czego dwadzieścia dziewięć w powiatach miejskim i ziemskim bytomskim/bytomsko-tarnogórskim. Początkowo przebywali w nich brytyjscy, francuscy i belgijscy jeńcy wojenni. W 1942 r. dołączyli do nich jeńcy sowieccy, a od 1944 r. także internowani żołnierze włoscy. Trudności na froncie wschodnim i konieczność ograniczenia produkcji w wielu zakładach, w latach 1942-1943, wymusiły zmianę profilu produkcji. Pojedyncze zakłady zaczęto włączać do firm zbrojeniowych. W $1943 \mathrm{r}$. wydobycie węgla na Górnym Śląsku osiągnęło $100 \mathrm{mln}$ ton. W Bytomiu, w wyniku nadmiernej eksploatacji złóż węgla bezpośrednio poza miastem, pojawiły się plany deglomeracji i przesiedlenia mieszkańców w okolice Pyskowic. Ostatecznie nie zostały zrealizowane. W styczniu 1945 r. w komandach roboczych w zakładach przemysłowych Bytomia i okolic znajdowało się ok. 9600 jeńców wojennych. W marszach śmierci, pieszo, przemieszczali się potem w głąb III Rzeszy. Baraki opustoszały.

Słowa kluczowe: Bytom, jeńcy wojenni, Stalagi VIII B i 318/VIII F Lamsdorf, Stalagi VIII D, VIII B/Z, VIII B Teschen, praca przymusowa, II wojna światowa 
Po ustaleniu granicy i podziale Górnego Śląska na część polską i niemiecką w 1922 r. Bytom zyskał charakter nadgraniczny. Został ograniczony w rozwoju przestrzennym. Każdy wolny skrawek, nawet w sąsiedztwie zakładów przemysłowych, intensywnie zabudowywano. W ten sposób powstały podmiejskie osiedla, które zasiedlili w latach międzywojnia m.in. optanci, czyli ci, którzy ze względów narodowościowych lub politycznych przenieśli się z terenów przyznanych Polsce do Niemiec.

Systematycznie wzrastała rola Bytomia jako ważnego na Górnym Śląsku ośrodka gospodarczego i administracyjnego. W mieście i najbliższej okolicy skoncentrowała się niemal połowa pozostałych w Niemczech zakładów przemysłu ciężkiego. Swoje siedziby ulokowały w nadgranicznym Bytomiu zarządy kilku znaczących koncernów. Miasto stało się niewątpliwie pewnego rodzaju oknem wystawowym również dla niemieckiej kultury, w Bytomiu działały teatry czy kina. Atrakcyjność dla potencjalnych przyjezdnych stanowiła duża liczba i różnorodność instytucji oświatowych. Bytom, co często powtarzano, był ostatnią ostoją niemczyzny na wschodnich rubieżach państwa.

W latach trzydziestych triumfy w Bytomiu zaczął odnosić narodowy socjalizm. W 1933 r. NSDAP osiągnęła w mieście trzeci wynik wyborczy w skali całych Niemiec. Granica dzieląca Górny Śląsk została zniesiona w 1939 r., po agresji III Rzeszy na Polskę. Wschodnie jego powiaty, dotąd polskie, na powrót wcielono do państwa niemieckiego. Górny Śląsk znów stanowił jednolitą całość administracyjną.

\section{Ku wojnie. Rozwój przemysłu na potrzeby gospodarki wojennej na Górnym Śląsku}

Po zakończeniu I wojny światowej sytuacja w zakładach przemysłowych na Górnym Śląsku ustabilizowała się w latach dwudziestych, po uprawomocnieniu się postanowień dotyczących podziału terenu spornego objętego plebiscytem oraz podpisaniu stosownych umów, tj. konwencji genewskiej i konwencji o ułatwieniach w małym ruchu granicznym. Podział administracyjny jednolitego dotąd obszaru skomplikował funkcjonowanie wielu kopalń, hut i zakładów z nimi kooperujących, a ich właściciele zostali zmuszeni do szybkich zmian o charakterze ekonomiczno-logistycznym. Korzystną koniunkturę zahamował kryzys 
gospodarczy, ograniczeniu uległo przede wszystkim wydobycie węgla. Celem polityki ekonomicznej po dojściu do władzy Adolfa Hitlera stało się odbudowanie pozycji politycznej, militarnej, ale i gospodarczej Niemiec. Zmiany te wiązały się również z postępującym interwencjonizmem ${ }^{1}$.

Polityka zagraniczna ministra gospodarki i prezesa Reichsbanku Rzeszy Niemieckiej - Hjalmara Schachta - doprowadziła w latach międzywojnia do izolacji Niemiec na arenie międzynarodowej. Model gospodarki sterowanej centralnie, który lansował, charakteryzował się planowaniem zadań i kontrolą państwa nad wszystkimi jej gałęziami². Spory kompetencyjne między Ministerstwem Gospodarki Rzeszy, Urzędem Gospodarki Obronnej i Uzbrojenia przy Okręgu Wojskowym Wehrmachtu oraz Urzędem ds. Planu Czteroletniego Rzeszy utrudniały sprawną realizację planowania. Poza tym znaczna liczba zakładów przemysłowych nadal pozostała w rękach prywatnych ${ }^{3}$. W 1938 r. tekę ministra gospodarki objął Walther Funk, natomiast Hermann Göring został mianowany pełnomocnikiem ds. realizacji planu czteroletniego, którego celem było powszechne zbrojenie i uzyskanie niezależności gospodarczej, na potrzeby prowadzenia działań militarnych ${ }^{4}$. Dążenia zmierzające do zbudowania sektora państwowego i uniezależnienia Rzeszy od dostaw surowców z zagranicy zintensyfikowano w drugiej połowie lat trzydziestych. W 1937 r. utworzono koncern Zakłady „Hermann Göring” (Reichswerke „Hermann Göring”). Formalnie stał się własnością III Rzeszy, składał się z wielu przejętych przez państwo większych i mniejszych przedsiębiorstw. W 1940 r., zgodnie z postanowieniem Urzędu Powierniczego Wschód (z 11 grudnia 1939), koncern przejął nadzór komisaryczny również nad wieloma zakładami przemysłowymi we wschodniej (w okresie międzywojnia: polskiej) części Górnego Śląska. W sierpniu 1944 r.

1 A. FrUŻyŃski, Historia przemystu górniczo-hutniczego w Bytomiu od początku wieku XVIII do roku 1939, [w:] Bytom i jego dziedzictwo w 750-lecie nadania praw miejskich. (Materiaty zinterdyscyplinarnej konferencji naukowej w Bytomiu w dniach 18-19 listopada 2004 r.), red. G. BożEK, Katowice 2004, s. 245; J. Dra BIna, Historia Bytomia 1254-2000, Bytom 2000, s. 221.

2 M. MASNy , Historia Górnego Ślaska. Polityka, gospodarka i kultura europejskiego regionu, Gliwice 2011, s. 234; J. Szpak, Historia gospodarcza powszechna, Warszawa 2003, s. 264. Vide: L. Próchnicki, $Z$ dziejów myśli ekonomicznej, Warszawa-Szczecin 2002.

${ }^{3}$ R. Kaczmarek, Pod rzadami gauleiterów. Elity i instancje wtadzy w rejencji katowickiej w latach 1939-1945, Katowice 1998, s. 144-145.

${ }^{4}$ J. Krasuski, Historia Niemiec, Wrocław-Warszawa-Kraków 2008, s. 436-441;Z.ZIeliński, Niemcy. Zarys dziejów, Katowice 2003, s. 236; E. KLEE, Walther Funk, [w:] Das Personenlexikon zum Dritten Reich. Wer war was vor und nach 1945, Hrsg. E. KLEE, Frankfurt am Main 2005, s. 172. 
w rękach III Rzeszy pozostawało ok. 260 zakładów, zlokalizowanych naturalnie nie tylko na Górnym Śląsku, ale niemal na całym terytorium III Rzeszy i terenów przez nią okupowanych ${ }^{5}$. Nadprezydenci i naczelnicy Prowincji Górnośląskiej - Josef Wagner, a potem Fritz Bracht - zmierzali do stworzenia na Górnym Śląsku centrum przemysłu ciężkiego, które byłoby porównywalne pod względem produkcji z Zagłębiem Ruhry w Nadrenii Północnej-Westfalii. Utrzymanie wskaźników produkcyjnych w dobie gospodarki wojennej zamierzano zapewnić nie poprzez inwestycje, ale wykorzystanie taniej siły roboczej, tj. jeńców wojennych, cywilnych pracowników przymusowych i więźniów obozów koncentracyjnych ${ }^{6}$.

Zainteresowanie Górnym Śląskiem jako regionem przemysłowym spadło w 1940 r., po wkroczeniu wojsk niemieckich na tereny Francji i Belgii, również rozwiniętych gospodarczo. Zakłady górnośląskie wymagały sporych nakładów finansowych i budowy sieci logistycznej, celem uruchomienia masowego transportu węgla i stali. Ponowne zainteresowanie regionem nastąpiło w 1942 r., w następstwie zniszczeń zakładów na zachodzie Europy, spowodowanych bombardowaniami oraz ograniczeniem możliwości pozyskiwania potrzebnych surowców na Wschodzie. Trudności natury administracyjnej czy uporządkowanie kwestii własnościowych, związanych z przejmowaniem majątku po obywatelach polskich i Żydach, powodowały jednak nadal wiele komplikacjī. Rozwój gospodarki wojennej na Górnym Śląsku skutecznie hamowało również włączanie kolejnych zakładów do koncernu „Hermann Göring”, uniemożliwiając wzmocnienie przedsiębiorstw przez kapitał prywatny ${ }^{8}$.

5 V.A. Stefanski, Arbeitseinsatz im Zeichen von Volkstumspolitik. Der oberschlesische Steinkohlenbergbau während des Zweiten Weltkrieges, [w:] Zwangsarbeit im Bergwerk. Der Arbeitseinsatz im Kohlenbergbau des Deutschen Reiches und der besetzten Gebiete im Ersten und Zweiten Weltkrieg, Bd. 1: Forschungen, Hrsg. K. Tenfelde, H.-Ch. Seidel, Essen 2005, s. 373-409; M. Riedel, Eisen und Koble für das Dritte Reich. Paul Pleigers Stellung in der NS-Wirtschaft, Göttingen-Frankfurt am Main-Zürich 1973; A. MeYer, Das Syndikat. Reichswerke „Hermann Göring”, Braunschweig 1986; H.-J. Bontrup, N. Zdrowomyslaw, Die Deutsche Rüstungsindustrie, Heilbronn 1988.

${ }^{6}$ Vide: A. Sulık, Przemyst ciężki rejencji katowickiej w gospodarce III Rzeszy (1939-1945), Katowice 1984 .

7 R. KaCZMAREK, op. cit., s. 149; G. SAATH, Die Industrie der angegliederten oberschlesischen Ostgebiete, Berlin-Prag-Wien 1942, s. 18-35; E. JĘDRZEJEWSKI, O niemieckiej administracji na terenach wtaczonych do rejencji opolskiej w latach 1939-1945, „Studia Śląskie” 1969, t. 16, s. 64.

8 A. Sulik, op. cit., s. 145-148, 172-180; W.A. BoelCKe, Die deutsche Wirtschaft 1930-1945. Interna des Reichswirtschaftsministerium, Düsseldorf 1983, s. 235-237; Norman Gibbs. Jeniec 
Rosnące straty III Rzeszy w związku z koniecznością ograniczenia produkcji w wielu zakładach oraz niepowodzenia na froncie wschodnim stały się w 1943 r. powodem zmiany profilu produkcyjnego. Kolejne zakłady włączano do koncernów zbrojeniowych (Zakłady „Hermann Göring”, I.G. Farbenindustrie AG czy Zakłady Friedricha Flicka), te zyskiwały przywileje w zakresie zaopatrzenia i zatrudniania. Na przełomie 1943 i 1944 r. łącznie zatrudniano 7,5 mln pracowników przymusowych, w tym 2 mln jeńców wojennych. Zaostrzono dyscyplinę, wydłużano czas pracy. Nadmierny wysiłek fizyczny, złe warunki bytowe i niedożywienie były przyczynami wypadków i chorób? raźnie osiągnięto jednak cel. W 1943 r. wskaźnik wydobycia węgla na Górnym Śląsku osiągnął $100 \mathrm{mln}$ ton. Eksportowano go do Generalnego Gubernatorstwa, Włoch i krajów skandynawskich ${ }^{10}$. Wówczas też większość zakładów przemysłu ciężkiego, w tym i te znajdujące się na terenie powiatów miejskiego i ziemskiego bytomsko-tarnogórskiego, osiągnęły apogeum wydajności. Nadmierna eksploatacja złóż węgla, bezpośrednio pod miastem, była przyczyną obaw przed ewentualną katastrofą budowlaną. Pojawiły się plany deglomeracji i przeniesienia mieszkańców miasta w rejon Pyskowic. Nie zostały one ostatecznie zrealizowane.

\section{Ze stalagów Lamsdorf i Teschen do komand roboczych}

W latach II wojny światowej władze niemieckie zorganizowały w III Rzeszy i na terenach przez nią okupowanych ponad 130 stałych obozów jenieckich. Do niewoli dostało się ok. $10 \mathrm{mln}$ żołnierzy pokonanych armii. Wielu z ich zwolniono lub jako pracowników cywilnych kierowano do pracy przymusowej.Ostatecznie do obozów jenieckich trafiło ok. $8 \mathrm{mln}$ mężczyzn ${ }^{11}$. Władze

wojenny nr 16349. Dziennik retrospektywny, oprac. J. Lusek, Bytom 2018, s. 20-24; P. DeUtsch, Die oberschlesische Montanindustrie vor und nach der Teilung des Industriebezirks, Bonn 1926.

9 J. Kaliński, Historia gospodarcza XIX i XX w., Warszawa 2008, s. 211.

10 A. Hornig, Transport wegla, brykietów i koksu na Śląsku w latach 1939-1945, „Zaranie Śląskie" 1963, z. 2, s. 297-300.

${ }^{11}$ Bundesarchiv - Militararchiv Freiburg, Oberkommando der Wehrmacht. Allgemeines Wehrmachtsamt, sygn. RW 6/v. 184, Monatliche Bestandesmeldung (1940-1944); H. SPECKNER, In der Gewalt des Feindes. Kriegsgefangenenlager in der „Ostmark” 1939-1945, Wien-München 2003, s. 25; P. StANeK, W niewoli niemieckiej. Informator wystawy statej Centralnego Muzeum Jeńców Wojennych w Eambinowicach-Opolu, Opole 2011, s. 5. 
niemieckie przygotowały kilka kategorii miejsc osadzenia. Pojmani trafiali najpierw do punktów zbornych (Sammelpunkte), skąd kierowano ich do obozów przejściowych - dulagów (Durchgangslager) lub bezpośrednio do obozów stałych - stalagów (Mannschaftsstammlager) dla żołnierzy szeregowych i podoficerów oraz oflagów (Offizierslager) dla oficerów. Jeńcy osadzeni w obozach podlegali izolacji i kontroli. Realizowano w nich cele polityczne, poprzez psychiczną i fizyczną ich eksterminację oraz ekonomiczne, poprzez nakaz pracy przymusowej w wielu gałęziach gospodarki ${ }^{12}$.

VIII Okręg Wojskowy Wehrmachtu z siedzibą we Wrocławiu obejmował przed wybuchem II wojny światowej Dolny Śląsk i niemiecką części Górnego Śląska, tj. rejencje opolską, legnicką i wrocławską. Po zajęciu Sudetów, granice okręgu uległy poszerzeniu o część rejencji opawskiej, w październiku zaś 1939 r. przyłączono do niego polską część Górnego Śląska, Zagłębie Dąbrowskie, Zaolzie oraz powiaty chrzanowski, olkuski, oświęcimski, wadowicki i żywiecki ${ }^{13}$. Władze okręgu nadzorowały obozy przejściowe, obozy dla oficerów, szeregowców i podoficerów, ponadto obozy dla cywilów i repatriacyjne. Siedziba dowódcy ds. jeńców wojennych, poczynając od 7 września 1940 r., znajdowała się we Wrocławiu. W marcu 1944 r. przeniesiono ją do Kopic. Po przejęciu obowiązków nadzorowania obozów dla jeńców wojennych przez SS, dowódca ds. jeńców wojennych okręgu podlegał dowódcy SS i policji we Wrocławiu - Obergruppenführerowi SS - Heinrichowi Schmauserowi ${ }^{14}$. Po ewakuacji obozów jenieckich z terenu okręgu dowództwo przeniesiono w styczniu 1945 r. do Zgorzelca (Görlitz), a w lutym do Liberca (Reichenberg), gdzie pozostało aż do kapitulacji Niemiec ${ }^{15}$.

W październiku 1939 r. w granicach VIII Okręgu Wojskowego Wehrmachtu wytyczono sześć okręgów nadzoru nad obozami jenieckimi, który

${ }^{12}$ G. Mattiello, W. Vogt, Deutsche Kriegsgefangenen-und Internierungseinrichtungen 1939-1945. Handbuch und Katalog. Lagergeschichte und Lagerzensurstempel, Bd. 1, Koblenz 1986, s. 8; J. Lusek, Obozy jenieckie Teschen w latach II wojny światowej, Český Těšín 2015, s. 2; H. SPECKNER, op. cit., s. 26-27.

13 S. Senft, H. WiĘCEK, Obozy jenieckie na obszarze Ślaskiego Okręgu Wehrmachtu 1939-1945, Wrocław-Warszawa-Kraków-Gdańsk 1972, s. 15; H. BATOwski, Terytorium Śląska w wiekach XIX-XX, zmiany granic i powierzchni 1740-1950, „Przegląd Zachodni” 1953, t. 3, nr 9/10, s. 358.

${ }_{14}$ Archiwum Państwowe w Katowicach (dalej: APK), 119, Rejencja Katowicka, sygn. 6282, k. 73-74; W. Keilig, Das deutsche Heer 1939-1945. Gliederung, Einsatz, Stellenbesetzung, Bad Neuheim 1956, s. 11.

15 W. KeIlig, op. cit., s. 17-19. 
pełniły Bataliony Strzelców Krajowych (Landesschützen-Bataillone). Wraz z rozpoczęciem wojny utworzono na tym terenie kilka obozów przejściowych - dulagów, w: Görlitz (Zgorzelec), Reichenbach (Dzierżoniów), Lamsdorf (Łambinowice), Sagan (Żagań), Halbau/Kunau (Iłowa Żagańska/Konin Żagański) i Öhringen (Sośnica pod Gliwicami). Trzy z nich, mające odpowiednią infrastrukturę na potrzeby przyjęcia większej liczby jeńców, przekształcono w obozy stałe dla żołnierzy szeregowych i podoficerów (stalagi), tj. w Zgorzelcu, Łambinowicach i Żaganiu (Stalag VIII A Görlitz, Stalag VIII B Lamsdorf i Stalag VIII C Sagan). W początkowej fazie konstruowania siatki obozów na Śląsku nie sprawowały one kontroli nad ściśle wytyczonym obszarem. Komanda pracy (Arbeitskommandos) dla osadzonych, wdrażanych w system pracy przymusowej, powstawały na terenie całej prowincji śląskiej, a ich podległością względem konkretnego obozu nie zawsze rządziły prawa logiki. Stalag VIII B Lamsdorf sprawował kontrolę nad oddziałami roboczymi w powiatach zielonogórskim, zgorzeleckim, a nawet łużyckim. Podlegało mu stosunkowo niewiele komand na Górnym Śląsku, ponieważ jeńcy nie byli wówczas jeszcze zatrudniani w przemyśle ciężkim. W kolejnych miesiącach zawężano rejony działalności obozów. W latach II wojny światowej pod kontrolą VIII Okręgu Wojskowego pozostawało łącznie jedenaście obozów jenieckich dla oficerów, jedenaście obozów jenieckich dla żołnierzy szeregowych i podoficerów, sześć obozów dla cywilów i obóz repatriacyjny ${ }^{16}$.

Do zakładów przemysłowych w Bytomiu trafiali w czasie II wojny światowej jeńcy osadzeni w kompleksach obozowych w Lamsdorf, tj. w Stalagu VIII B Lamsdorf oraz 318/VIII F Lamsdorf, jak również jego filii - Stalagu VIII B/Z Teschen, po zmianach administracyjnych jeńcy osadzeni w Teschen, tj. Stalagu VIII D Teschen i Stalagu VIII B Teschen. Obejmowały zasięgiem wschodnią część VIII Okręgu Wojskowego Wehrmachtu, tj. rejencje opolską, katowicką

16 R. Kobylarz, K. Sznotala, Wykaz niemieckich obozów jenieckich 1939-1945, Opole 2010, s. 34-35; J. SAWCZU K, S. SENFT, Obozy jenieckie w Lamsdorf w latach II wojny światowej, [w:] Obozy $w$ Lamsdorf/Eambinowicach (1870-1946), red. E. Nowak, Opole 2006, s. 134; G. MatTiello, W. VoGt, Deutsche Kriegsgefangenen-und Internierungseinrichtungen..., Bd. 1, s. 20; Koblenz 1987, Bd. 2, s. 67-68; J. Lusek, A. Goetze, Stalag VIII A Görlitz. Historia - teraźniejszość - przysztość, „Łambinowicki Rocznik Muzealny” (dalej: ŁRM) 2011, t. 34, s. 27-28; P. STAnEK, J. Ter PińsKa-Greszczeszyn, W cieniu „wielkiej ucieczki”. Kompleks obozów jenieckich Sagan (1939-1945), ERM 2011, t. 34, s. 125-127. 
i opawską ${ }^{17}$. Ich jurysdykcji podlegały komanda pracy dla jeńców o różnej przynależności armijnej, utworzone w rejencji katowickiej, m.in. na terenach powiatu bytomskiego/bytomsko-tarnogórskiego miejskiego i ziemskiego.

W Stalagu VIII B Lamsdorf do wiosny 1940 r. pozostawali wyłącznie jeńcy polscy, wówczas też rozpoczęto masową akcję ich przesuwania do obozów w głąb III Rzeszy. Działania władz niemieckich podyktowane były koniecznością przygotowania miejsca na przyjęcie transportów jenieckich $\mathrm{z}$ frontu zachodniego ${ }^{18}$. Pierwotnie władze niemieckie zakładały, że przygotowane obozy będą jednolite pod względem przynależności armijnej osadzanych w nich żołnierzy, co usprawnić miało kontrolę i utrzymanie względnego porządku, szczególnie wśród oczekujących na przydział do komand pracy. Wzrost liczby osadzonych w 1940 i 1941 r. oraz uwarunkowania polityczne, które doprowadziły do wybuchu wojny między III Rzeszą a Związkiem Radzieckim i pojawienia się w obozach jeńców sowieckich zniweczyły ów plan. Wówczas też utworzono Stalag 318/VIII F Lamsdorf ${ }^{19}$.

Wiosną 1941 r. powstał Stalag VIII D Teschen. Spełniał on zadania tzw. Schattenlager - obozu ukrytego (dosł. obóz w cieniu). Jego zadania związane były z zabezpieczeniem nadzoru nad komandami roboczymi, realizującymi zadania na cele gospodarki wojennej. Nie posiadał własnego rejonu administracyjnego, pełnił wyłącznie rolę służebną wobec stalagów w Lamsdorf ${ }^{20}$. Peryferyjne położenie kompleksu względem komand pracy, zlokalizowanych na terenie strategicznym dla gospodarki III Rzeszy, tj. Górnym Śląsku i Zagłębiu Ostrawsko-Karwińskim, uniemożliwiało sprawne prowadzenie czynności administracyjno-nadzorczych. Decyzją z 16 września 1942 r. zlikwidowano Stalag VIII D Teschen i przekształcono w filię Stalagu VIII B Lamsdorf - Stalag VIII B/Z Teschen $^{21}$. W 1943 r. w kompleksie Lamsdorf przebywało ok. 120000 jeńców.

${ }^{17}$ J. SAwCZuK, S. Senft, op. cit., s. 136.

18 Vojenský ústřední archiv v Praze (dalej: VÚA), Stalag VIII B, sygn. 316/1/58, Lagerberichte 1939 i 1940.

19 Archiwum Centralnego Muzeum Jeńców Wojennych (dalej: ACMJW), Materiały i Dokumenty. Raporty, sygn. 18, Wizytacja z 13 czerwca 1941 r., k. 4.

${ }^{20}$ H. Speckner, op. cit., s. 27; G. Mattiello, W. Vogt, op. cit., Bd. 1, s. 8.

${ }^{21}$ Z. KoneČny, F. MaInUš, Obozy jenieckie na Górnym Śląsku ( $z$ dziejów stalagu cieszyńskiego), red. A. Szefer, Katowice 1969, s. 8; G. Tessin, Verbände und Truppen der deutschen Wehrmacht und Waffen SS im Zweiten Weltkrieg 1939-1945. Bd. 3, Frankfurt am Main 1974, s. 113; J. LusEK, Obozy jenieckie Teschen..., s. 6-7; M. KRŮL, Stavebni vývoj kmenových táborů Teschen a počty jejich válečných zajatcü, [w:] Čas - mista - lidé. Systém nacistických táborů v letech drubé svètové války / 
Ponad 90000 z nich zatrudniano w komandach roboczych, w tym w przemyśle ciężkim $^{22}$. Rozważano wówczas utworzenie kolejnego obozu - Stalagu VIII G Mechtal (w Miechowicach), celem przejęcia przez niego nadzoru nad górnośląskimi zakładami przemysłowymi, m.in. w powiecie bytomsko-tarnogórskim lub ponowne usamodzielnienie filii w Teschen. W grudniu $1943 \mathrm{r}$. zadecydowano o rozdziale kompetencji między stalagami Lamsdorf i Teschen i przeniesieniu komendantury do Stalagu VIII B Teschen. Objął on zasięgiem rejencję katowicką oraz powiat zawierciański, wydzielony z rejencji opolskiej. W latach 1944-1945 obóz jeniecki w Teschen sprawował nadzór nad ponad 70000 jeńcami. Nowo utworzony, w wyniku zmian administracyjnych, Stalag 344 Lamsdorf objął zasięgiem rejencje opawską i opolską, pod jego nadzorem pozostawało około 50000 jeńców. Stalag ów, poza realizacją standardowych zadań, pełnił funkcje obozu przejściowego dla jeńców, którzy mieli być zatrudniani w rejonie działania Stalagu VIII B Teschen. Trwale lub czasowo niezdolnych do pracy, odsyłano jednak nie do Teschen, a do Lamsdorf. Zdrowych, po rekonwalescencji, ponownie kierowano do pracy w wyznaczonych komandach, w rejonie administracyjnym Stalagu VIII B Teschen. Zależność między obydwoma obozami - Lamsdorf i Teschen - w zakresie obsługi jeńców, na potrzeby tego drugiego utrzymała się do chwili ewakuacji stalagów i podległych im komand, czyli do stycznia $1945 \mathrm{r}^{23}$

Dokumentem regulującym zasady postępowania wobec jeńców w konfliktach międzynarodowych, analogicznie również zatrudniania jeńców wojennych, była konwencja genewska. W czasie II wojny światowej do pracy przymusowej włączano masowo żołnierzy szeregowych i podoficerów osadzanych w stalagach. Niewielu z nich otrzymywało pracę w obozach macierzystych, w których wykonywali najczęściej zadania o charakterze porządkowym, budowlanym, rzadziej zaś administracyjnym. Władze niemieckie respektowały zakaz zmuszania

Czas - miejsca - ludzie. Nazistowski system obozowy w latach drugiej wojny światowej, red. M. KRŮL, J. Lusek, Bytom-Český Těšín 2017, s. 108-117.

22 ACMJW, Mikrofilmy, sygn. 1-R III (Mikrofilm Moskiewski), skan nr 188; J. SAWCZUK, S. SENFT, op. cit., s. 135.

${ }^{23}$ J. LuSEK, Obozy jenieckie Teschen..., s. 6-7; J. SAWCZUK, Hitlerowskie obozy jenieckie w Eambinowicach w latach 1939-1945, Opole 1974, s. 46; J. SAWCZUK, S. SENFT, op. cit., s. 152-167. Vide: R. Majewski, VIII Okregg Wojskowy Wehrmachtu we Wroctawiu (1936-1945) (Studium historyczno-wojskowe), Wrocław 1991. 
do pracy oficerów osadzonych w oflagach. Wyjątek stanowili jeńcy sowieccy, których obowiązywał rygor pracy bez względu na stopień wojskowy ${ }^{24}$.

Konwencja genewska określała precyzyjnie formy pracy, które mogły być wykonywane przez jeńców wojennych: 1. praca dozwolona bez ograniczeń, tj. dotycząca czynności administracyjnych, przygotowania i utrzymywania obozów jenieckich i miejsc, w których przebywali osadzeni; praca w rolnictwie; praca w handlu; działalność artystyczna i rzemieślnicza; służba domowa, 2. praca niemająca przeznaczenia wojskowego, tj. praca w przemyśle, z wyłączeniem przemystu metalowego, maszynowego i chemicznego; praca w transporcie; praca na kolei; praca w służbach porządkowych i instytucjach użyteczności publicznej, 3. zabronione formy pracy, tj. praca w przemyśle metalowym, maszynowym i chemicznym, praca przy wykonywaniu robót publicznych i budowlanych o charakterze i przeznaczeniu wojskowym. Zakaz nie obejmował zatrudniania jeńców wojennych w przemyśle surowcowym i wydobywczym ${ }^{25}$. Zapotrzebowanie III Rzeszy na tanią siłę roboczą stało się podstawą dla utworzenia sieci oddziałów roboczych - komand pracy. Każdy oddział otrzymywał numer, według kolejności tworzenia. W powiatach funkcjonowało od kilku do kilkudziesięciu komand. W powiecie bytomskim/bytomsko-tarnogórskim było ich dwadzieścia dziewięć, w samym Bytomiu funkcjonowało sześć komand ${ }^{26}$.

Jeńcom wojennym należało zapewnić odpowiednie warunki pracy w kwestii bezpieczeństwa i higieny pracy. Ci zatrudniani w zakładach przemysłowych

${ }^{24}$ J. Sawczuk, S. Senft, op. cit., s. 164-165; M. Fleming, Jeńcy wojenni: Studium prawno-historyczne, Warszawa 2000, s. 167-168; W. Lemiesz, Praca przymusowa jeńców wojennych w Niemczech w latach II wojny światowej, Zielona Góra 1969, s. 96-97; A. KonIECZny, Rozmiary zatrudniania zagranicznych robotników przymusowych i jeńców wojennych w gospodarce Dolnego Ślqska w latach II wojny światowej, „Studia Śląskie” 1968, t. 13, s. 276; M. SPOeRER, Zwangsarbeit unter dem Hakenkreuz. Ausländische Zivilarbeiter, Kriegsgefangene und Häftlinge im Deutschen Reich und im besetzten Europa 1939-1945, Stuttgart 2001, s. 223-224; J.C. WAGNER, Zwangsarbeit im Nationalsozialismus - ein Überblick.Zwangsarbeit, [w:] Die Deutschen, die Zwangsarbeiter und der Krieg. Begleitband zur Ausstellung, Hrsg. V. Knigge, R.G. Luttgenau, J.C. Wagner, Weimar 2010, s. 180-181; J. LuseK, Wystawa „Praca przymusowa. Niemcy, pracownicy przymusowi i wojna" (Zwangsarbeit. Die Deutschen, die Zwangsarbeiter und der Krieg. Berlin), 27 września 2010 - 31 stycznia 2011, ŁRM 2011, t. 34, s. 177-183.

${ }^{25}$ H.S. Levie, The Employment of Prisoners of War, „American Journal of International Law” 1963, vol. 57, s. 330-333; Norman Gibbs..., s. 27-29.

${ }^{26}$ VÚA, Stalag VIII B, sygn. 1104/71/D; ACMJW, Materiały i Dokumenty (dalej: MiD), Kartoteka oddziałów roboczych Stalagu VIII B. 
mieli być kwaterowani bezpośrednio przy zakładach. Zakazano im swobodnego przemieszczania się. Osadzeni mieli prawo poruszania się wyłącznie na trasie pomiędzy barakami a miejscem pracy. Warunki bytowe jeńców w komandach nie powinny były odbiegać od warunków jeńców przebywających w obozie macierzystym, mając na uwadze: wyżywienie, warunki higieniczno-bytowe, dostęp do opieki medycznej czy do paczek czerwonokrzyskich. Jeńcom należało zapewnić odzież roboczo-ochronną (kombinezony), adekwatnie do rodzaju wykonywanej pracy ${ }^{27}$.

Podczas II wojny światowej utrzymano zwyczaj wypłacania jeńcom wynagrodzenia za świadczoną pracę. Nie przysługiwało ono pracującym w obozach macierzystych, za pracę związaną z budową baraków i ich utrzymaniem. Wyjątek stanowiły zawody tj. krawiec, szewc, fryzjer czy pracownik pralni. Wynagrodzenie wypłacano w tzw. pieniądzach obozowych - lagermarkach. Wysokość kwoty uwarunkowana była przynależnością armijną osadzonych oraz zaszeregowaniem do grupy pracowników wykwalifikowanych lub niewykwalifikowanych ${ }^{28}$. W myśl konwencji genewskiej jeńców należało kierować do takiej pracy fizycznej, do wykonywania której byli zdolni. Rozróżniano cztery kategorie zdolności do pracy: praca ciężka, praca lekka, niezdolność do pracy fizycznej, niezdolność do pracy w ogóle. Władze niemieckie negatywnie odnosiły się do wniosku Międzynarodowego Komitetu Czerwonego Krzyża (dalej: MKCK), co do zwalniania z pracy w kopalniach jeńców, którzy ukończyli 45 rok życia. Ostatecznie decyzję, co do ich przeniesienia lub odroczenia obowiązku pracy, podejmowały władze obozowe ${ }^{29}$. Podstawą dla określania wysokości wynagrodzenia jeńców wojennych były zarobki robotników niemieckich w danym zakładzie pracy i stopień zaszeregowania według niemieckiego taryfikatora. Jeńcom nie przysługiwały dodatki za pracę w niedziele, święta, jak też godziny nadliczbowe. Z ogólnej sumy wynagrodzenia odtrącano $10 \%$ ryczałtu, który przesyłano do komendantury obozu

27 M. Fleming, op. cit., s. 142-143, 176, 181-182; A. WiCKIewiCz, Niewola w brytyjskim mundurze. Stalag VIII B (344) Lamsdorf, Opole 2016, s. 79-87; J. LusEK, Opieka medyczna nad żotnierzami brytyjskimi w obozach jenieckich "Lamsdorf” i „Teschen” w latach II wojny światowej, [w:] Čas - mista - lidé..., s. 132-134; J. SAwCzU K, Hitlerowskie obozy jenieckie..., s. 134, 143-144.

${ }^{28}$ H.S. Levie, op. cit., s. 324; A. WiCKIEW ICZ, op. cit., s. 82; J.A. KUJAT, Pieniądz zastępczy wobozach jenieckich na terenie rejencji wroctawskiej w czasie I i II wojny światowej, ŁRM 2000, t. 23, s. $16-23$.

29 M. Fleming, op. cit., s. 180. 
macierzystego. Jeńców zatrudnionych w kopalniach dzielono na grupy w zależności od efektywności wykonywanej pracy, co wiązało się z przywilejami przy rozdziale żywności. Do pierwszej grupy należeli najwydajniej pracujący (wydajność ponad $80 \%$ normy), otrzymywali dodatkowe racje żywności, w tym owoce oraz papierosy. Zakwalifikowani do drugiej grupy (wydajność między 60-80\% normy) otrzymywali dodatkowo przydział papierosów. Najmniej efektywni (do 60\% normy) nie otrzymywali dodatkowych racji. Formy oporu i akcje sabotażowe karane były odbieraniem dodatków i zmniejszeniem wynagrodzenia czy wydłużeniem czasu pracy ${ }^{30}$.

Czas pracy wyznaczano na podstawie rozporządzenia z 2 marca 1939 r. W związku z koniecznością zachowania ciągłości produkcji w zakładach przemysłu ciężkiego jedną niedzielę w miesiącu typowano jako pracującą (tzw. Sonntagspflichtschicht). W 1943 r. ich liczbę podniesiono do dwóch w miesiącu. Czas pracy ustalono początkowo na 8 godzin dziennie. 1 czerwca 1940 r. wydłużono go do 8 godzin i 45 minut. Zgodnie z rozporządzeniem z 31 sierpnia 1944 r. mężczyźni pracowali do 60 godzin tygodniowo, kobiety i młodzież powyżej 16. roku życia - 56 godzin tygodniowo, dzieci poniżej 16 roku życia - 48 godzin tygodniowo ${ }^{31}$. W sprawozdaniach dyrektorzy kopalń byli zobligowani podawać liczbę godzin przepracowanych w systemie nadliczbowym ${ }^{32}$.

Początkowo wstrzymywano się z wydaniem zezwolenia na wprowadzanie jeńców wojennych do zakładów przemysłowych, głównie kopalń, ze względów bezpieczeństwa. Jednocześnie władze niemieckie dopuściły możliwość składania podań, celem ich zatrudniania w konkretnych zakładach, w systemie miesięcznym ${ }^{33}$. Utrzymanie ciągłości produkcji wymusiło jednak ich stałe zatrudnianie. Tylko na przełomie 1940 i 1941 r. na Górny Śląsk przybyło ponad

30 APK, 703, Urząd Górniczy Bytom-Północ, sygn. 199, Ausländische Arbeiter (1938-1944), k. 468-469 (Beuthen, Karsten-Zentrum-Grube, 30 VIII 1943), k. 419-422 (24 VIII 1943); Z. Konečny, F. Mainuš, op. cit., s. 29-31, 34.

${ }^{31}$ APK, 703, sygn. 152, Arbeitszeit (1936-1944), k. 125 i 130, k. 200, 236; sygn. 86, Sonntagsruhe (1938-1944), k. 74.

32 APK, 703, sygn. 152, k. 189; 704, Urząd Górniczy Bytom-Południe, sygn. 77, Arbeitszeit (1930-1944), k. 122; sygn. 181, Sonntagsruhe (1938-1944), k. 28, 35 i 50.

33 APK, 703, sygn. 152, k. 130; sygn. 199, k. 27-28, Berlin, 16 X 1939 (Einsatz von Kraften aus den von den deutschen Truppen besetzten Gebieten der Republik Polen); Berlin 19 X 1939 (Einsatz von polnischen Kriegsgefangenen). 
2000 jeńców (Brytyjczyków, Francuzów i Belgów), o czym świadczą wnioski, składane przez dyrektorów poszczególnych zakładów. W kolejnych latach liczba ta wzrosła do kilkudziesięciu tysięcy ${ }^{34}$. Od sierpnia 1942 r. w przemyśle ciężkim zatrudniano także jeńców sowieckich. W latach 1942-1944 praca w górnictwie zdominowała inne gałęzie przemysłu, obejmowała ponad połowę zatrudnionych na Górnym Śląsku ${ }^{35}$. Skalę zjawiska potwierdzają zachowane sprawozdania władz obozowych i zakładów przemysłowych. W 1943 r. Stalagi VIII B i VIII F Lamsdorf wysłały do pracy w kopalniach 18 700-26 500 jeńców, co stanowiło ok. 44-46\% ogółu jeńców zatrudnianych w komandach roboczych. Ta tendencja utrzymała się także w 1944 r. Wówczas do zakładów przemysłu ciężkiego wysłano również ok. 40000 internowanych żołnierzy włoskich ${ }^{36}$. W latach wojny obozy Lamsdorf i Teschen kontrolowały łącznie ponad 1000 komand pracy dla jeńców radzieckich, 800 dla jeńców brytyjskich i 500 dla internowanych żołnierzy włoskich, ponadto komanda pracy dla jeńców polskich, francuskich, belgijskich, serbskich i greckich ${ }^{37}$.

\section{Komanda robocze dla jeńców wojennych w Bytomiu}

Powiat bytomski/bytomsko-tarnogórski miejski i ziemski (Stadtkreis Beuthen oraz Landkreis Beuthen) został włączony w latach II wojny światowej w granice rejencji katowickiej. Zakłady przemysłu ciężkiego na tym terenie podlegały Urzędowi Górniczemu Bytom-Północ (Bergamt Beuthen-Nord) i Urzędowi Górniczemu Bytom-Południe (Bergamt Beuthen-Süd), fragmentarycznie natomiast Urzędowi Górniczemu Gliwice-Północ (Bergamt Gleiwitz-Nord). Powiat miejski, który stanowi główny punkt odniesienia dla dalszej analizy

${ }_{34}$ APK, 703, sygn. 200, Kriegsgefangene (1940-1944), k. 36, 47 i 83; 704, sygn. 93, Ausländer (1940-1944), k. 56-58.

35 A. Konieczny, op. cit., s. 276; J. Sawczu K, S. Senft, op. cit., s. 164; A. Rat Kow Ski, Wykorzystanie przez hitlerowców jeńców wojennych w gospodarce Górnego Ślaska, [w:] Z lat wojny i okupacji 1939-1945, t. 7, red. M. Anusiew ICZ, L. Grot, Warszawa 1977, s. 230-258.

36 APK, 704, sygn. 189, Verkehr mit den Arbeitsämtern (1944), k. 9 (Umsetzung von Arbeitskräften zum Bergbau, 16 III 1944).

${ }^{37}$ ACMJW, Mikrofilmy, Mikrofilm moskiewski, sygn. 1-R II, 1-R III; Mikrofilm praski, sygn. 2-R I, 2-R II, dot. zatrudniania jeńców radzieckich przemyśle ciężkim w latach 1942-1944; J. SAWCZuK, S. Senft, op. cit., s. 162-166 (Tabele 8 i 9); A. KonieCZny, op. cit., s. 276. 
w niniejszym artykule, podlegał częściowo pod Urząd Górniczy Bytom-Północ i Urząd Górniczy Bytom-Południe ${ }^{38}$.

Wdrażanie jeńców wojennych do zakładów przemysłowych rozmieszczonych na terenie miasta rozpoczęło się w drugiej połowie 1940 r. Pojawienie się znacznej liczby osadzonych w zakładach przemysłowych wymagało wprowadzenia odpowiednich procedur administracyjnych związanych z nadzorem, przygotowaniem miejsc zakwaterowania, wyżywieniem czy organizacją opieki medycznej. Odpowiedzialność za sprawną realizację przydzielonych zadań powierzono komendantom komand roboczych, przedstawicielom urzędów pracy oraz zarządzającym zakładami dyrektorom. Każdy z podmiotów prowadził niezależną ewidencję, celem informowania przełożonych, tj. obóz macierzysty czy urzędy górnicze, o aktualnym stanie poszczególnych komand. Odnotowywano m.in. liczbę zatrudnionych jeńców, liczbę przybywających w transportach, wypadkowość i przypadki śmiertelne, przypadki ucieczek czy sabotaży, wysokość wypłacanych za pracę poborów ${ }^{39}$.

W latach II wojny światowej w powiecie bytomskim/bytomsko-tarnogórskim miejskim i ziemskim prowadzono łącznie dwadzieścia dziewięć komand roboczych, w tym jedenaście dla jeńców brytyjskich, czternaście dla jeńców sowieckich, jedno dla jeńców serbskich, jedno dla jeńców belgijskich oraz dwa komanda dla internowanych żołnierzy włoskich (Tabela 1). Sześć z nich, kluczowych dla dalszej części opracowania, przeznaczonych dla jeńców brytyjskich, sowieckich i internowanych żołnierzy włoskich, znajdowało się na terenie miasta.

38 APK, 703, sygn. 355, Zusammenarbeit mit der Sicherpolizei (1943-1944), k. 58-63 (sprawozdania za okres 21-30 października 1943).

39 APK, 703, sygn. 200, k. 1 (Beuthen, 17 VII 1940). 
Tabela 1

\section{Zestawienie komand pracy dla jeńców wojennych w powiecie bytomskim/bytomsko-tarnogórskim miejskim i ziemskim $(1940-1945)^{40}$}

\begin{tabular}{|l|l|l|}
\hline $\begin{array}{c}\text { Oznaczenie } \\
\text { komanda }\end{array}$ & \multicolumn{1}{|c|}{ Miejsce osadzenia } & \multicolumn{1}{|c|}{ Pracodawca } \\
\hline \multicolumn{2}{|c|}{ 1. Komanda pracy dla jeńców brytyjskich } \\
\hline E 51 & Mikulczyce, powiat ziemski & $\begin{array}{l}\text { Abwehrgrube } \\
\text { Kopalnia „Mikulczyce” }\end{array}$ \\
\hline E 72 & Szombierki, powiat ziemski & $\begin{array}{l}\text { Hohenzollerngrube } \\
\text { Kopalnia „Szombierki” }\end{array}$ \\
\hline E 209 & Bobrek-Karb, powiat ziemski & $\begin{array}{l}\text { Gräfin Johanna Schacht } \\
\text { Kopalnia „Bobrek”, szyb „Józef” }\end{array}$ \\
\hline E 411 & Szombierki, powiat ziemski & $\begin{array}{l}\text { Hohenzollerngrube } \\
\text { Kopalnia „Szombierki” } \\
\text { OSTHOLZ } \\
\text { Brykietownia }\end{array}$ \\
\hline E 490 & Bytom, powiat miejki & $\begin{array}{l}\text { Eisenbeton und Hochbau } \\
\text { Zakład mistrza murarskiego Roberta Matusska }\end{array}$ \\
\hline E 593 & Szombierki, powiat ziemski & $\begin{array}{l}\text { Hohenzollerngrube } \\
\text { Kopalnia „Szombierki” }\end{array}$ \\
\hline E 727 & Miechowice, powiat ziemski & $\begin{array}{l}\text { Schlesische Elektrizitäts- und Gas A.G. Gleiwitz } \\
\text { Śląskie Stowarzyszenie Elektryczno-Gazowe w } \\
\text { Gliwicach }\end{array}$ \\
\hline E 748 & Bobrek, powiat ziemski & $\begin{array}{l}\text { Reichsbahnenbauamt } \\
\text { Urząd Rozbudowy Kolei }\end{array}$ \\
\hline E 760 761 & Bobrek, powiat ziemski & $\begin{array}{l}\text { Schmalspuramt } \\
\text { Urząd Kolei Wąskotorowych }\end{array}$ \\
\hline Bobrek, powiat ziemski & $\begin{array}{l}\text { Verkehrsbetrieb } \\
\text { Zakład transportowy }\end{array}$ \\
\hline Bobrek, powiat ziemski & $\begin{array}{l}\text { Beton und Monierbetrieb } \\
\text { Wytwórnia betonu }\end{array}$ \\
\hline
\end{tabular}

${ }^{40}$ Komanda pracy znajdujące się na terenie powiatu bytomskiego/bytomsko-tarnogórskiego miejskiego kluczowe dla niniejszego opracowania podkreślono na szaro. 
Tabela 1 (cd.)

\begin{tabular}{|c|c|c|}
\hline $\begin{array}{c}\text { Oznaczenie } \\
\text { komanda }\end{array}$ & Miejsce osadzenia & Pracodawca \\
\hline \multicolumn{3}{|c|}{ 2. Komanda pracy dla jeńców sowieckich } \\
\hline R 35 & Bobrek, powiat ziemski & $\begin{array}{l}\text { Julienhütte } \\
\text { Huta „Bobrek” }\end{array}$ \\
\hline R 97 & Miechowice, powiat ziemski & $\begin{array}{l}\text { Hermann Göring Werke } \\
\text { Zakłady „Hermann Göring” }\end{array}$ \\
\hline R 99 & Szombierki, powiat ziemski & $\begin{array}{l}\text { Hohenzollerngrube } \\
\text { Kopalnia „Szombierki” }\end{array}$ \\
\hline R 101 & Bytom, powiat miejski & $\begin{array}{l}\text { Karsten-Zentrum-Grube } \\
\text { Kopalnia „Centrum” }\end{array}$ \\
\hline R 105 & Bytom, powiat miejski & $\begin{array}{l}\text { Beuthengrube } \\
\text { Kopalnia „Powstańców Śląskich” }\end{array}$ \\
\hline R 179 & Bobrek-Karb, powiat ziemski & $\begin{array}{l}\text { Gräfin Johanna Schacht } \\
\text { Kopalnia „Bobrekk”, szyb „Józef” }\end{array}$ \\
\hline R 194 & Mikulczyce, powiat ziemski & $\begin{array}{l}\text { Abwehrgrube } \\
\text { Kopalnia „Mikulczyce” }\end{array}$ \\
\hline R 263 & Bobrek-Karb, powiat ziemski & $\begin{array}{l}\text { Karbitwerk } \\
\text { Kopalnia „Bobrek”, karbidownia }\end{array}$ \\
\hline R 276 & Bobrek-Karb, powiat ziemski & $\begin{array}{l}\text { Julienhütte } \\
\text { Huta „Bobrek” }\end{array}$ \\
\hline R 366 & Miechowice, powiat ziemski & $\begin{array}{l}\text { Schlesische Elektrizitäts- und Gas A.G. Gleiwitz } \\
\text { Śląskie Stowarzyszenie Elektryczno-Gazowe w } \\
\text { Gliwicach }\end{array}$ \\
\hline R 657 & Bytom-Rozbark, powiat miejski & $\begin{array}{l}\text { Heinitzgrube } \\
\text { Kopalnia „Rozbark” }\end{array}$ \\
\hline R 734 & Bobrek-Karb, powiat ziemski & $\begin{array}{l}\text { Julienhütte } \\
\text { Huta „Bobrek” }\end{array}$ \\
\hline R914 & Bytom, powiat miejski & $\begin{array}{l}\text { Luftgau-Kommando VIII } \\
\text { Siły Powietrzne VIII Okręgu Wojskowego We- } \\
\text { hrmachtu, koszary }\end{array}$ \\
\hline R 973 & Mikulczyce, powiat ziemski & $\begin{array}{l}\text { Abwehrgrube } \\
\text { Kopalnia „Mikulczyce” }\end{array}$ \\
\hline \multicolumn{3}{|c|}{ 3. Komanda pracy dla jeńców serbskich } \\
\hline S 198 & Bobrek, powiat ziemski & $\begin{array}{l}\text { Gräfin Johanna Schacht } \\
\text { Kopalnia „Bobrek”, szyb „Józef” }\end{array}$ \\
\hline \multicolumn{3}{|c|}{ 4. Komanda pracy dla jeńców belgijskich } \\
\hline F 150 & Miechowice, powiat ziemski & $\begin{array}{l}\text { Preussengrube } \\
\text { Kopalnia „Miechowice” }\end{array}$ \\
\hline
\end{tabular}




\begin{tabular}{|l|l|l|}
\hline \multicolumn{3}{|c|}{ 5. Komanda pracy dla internowanych żołnierzy włoskich } \\
\hline It 7 & Bobrek-Karb powiat ziemski & $\begin{array}{l}\text { Julienhütte } \\
\text { Huta „Bobrek” }\end{array}$ \\
\hline It 21 & Bytom, powiat miejski & $\begin{array}{l}\text { Beuthengrube } \\
\text { Kopalnia „Powstańców Śląskich” }\end{array}$ \\
\hline
\end{tabular}

Źródło: Norman Gibbs. Jeniec wojenny nr 16349. Dziennik retrospektywny, oprac. J. LusEK, Bytom 2018, s. $178-179$.

\subsection{Komanda robocze E 72, R 105 i It 21}

Kopalnia „Beuthengrube” (po wojnie kopalnia „Bytom”, „Powstańców Śląskich”, obecnie nie istnieje) w Dąbrowie Miejskiej została zbudowana w latach 1922-1928, w części pola górniczego kopalni „Radzionków”, po stronie niemieckiej. Znajdowała się w posiadaniu koncernu The Henckel von Donnersmarck-Beuthen Estates Limited. W czasie II wojny światowej na terenie kopalni „Beuthengrube” funkcjonowały trzy komanda, jedno komando dla jeńców brytyjskich oraz dwa komanda dla jeńców sowieckich.

Komando dla jeńców brytyjskich - E 72 - prowadzono początkowo na kopalni „Beuthengrube”, następnie przeniesione zostało do kopalni „Hohenzollern”, zlokalizowanej nieopodal miasta, w Szombierkach. Obydwie kopalnie połączone były podziemnymi pokładami. Jeńcy pracowali w tych wyrobiskach, w których byli potrzebni. W październiku 1941 r. przebywało w nim 171 Brytyjczyków. W kolejnych miesiącach liczba jeńców dynamicznie wzrastała. W marcu 1942 r. w kopalni zatrudniano 204 jeńców, we wrześniu - 444. W kolejnym roku ponad 600 mężczyzn. Wówczas też, z uwagi na liczebność, komando poddawano regularnym wizytacjom ze strony władz obozowych w Lamsdorf i przedstawicieli MKCK. Jeńcy sowieccy rozpoczęli pracę w kopalni w sierpniu $1941 \mathrm{r}$. Pierwszy transport liczył 150 mężczyzn. W 1943 r. komando R 105 podlegało kontroli władz obozowych. Adnotacje na ich temat miały lakoniczny charakter. W marcu i listopadzie $1943 \mathrm{r}$. donoszono w sprawozdaniach o znacznej liczbie chorych i niewystarczającym zaopatrzeniu w żywność, w tym w ziemniaki. Jesienią 1944 r. informowano w protokole, że jeden z jeńców przekupił niemieckiego maszynistę, celem pomocy jeńcom radzieckim w ucieczkach w wagonach z węglem. Sabotaż naturalnie wykryto. Winnych ukarano. W styczniu 1945 r., tuż przed ewakuacją, w komandzie przebywało 635 mężczyzn. W 1943 r. 


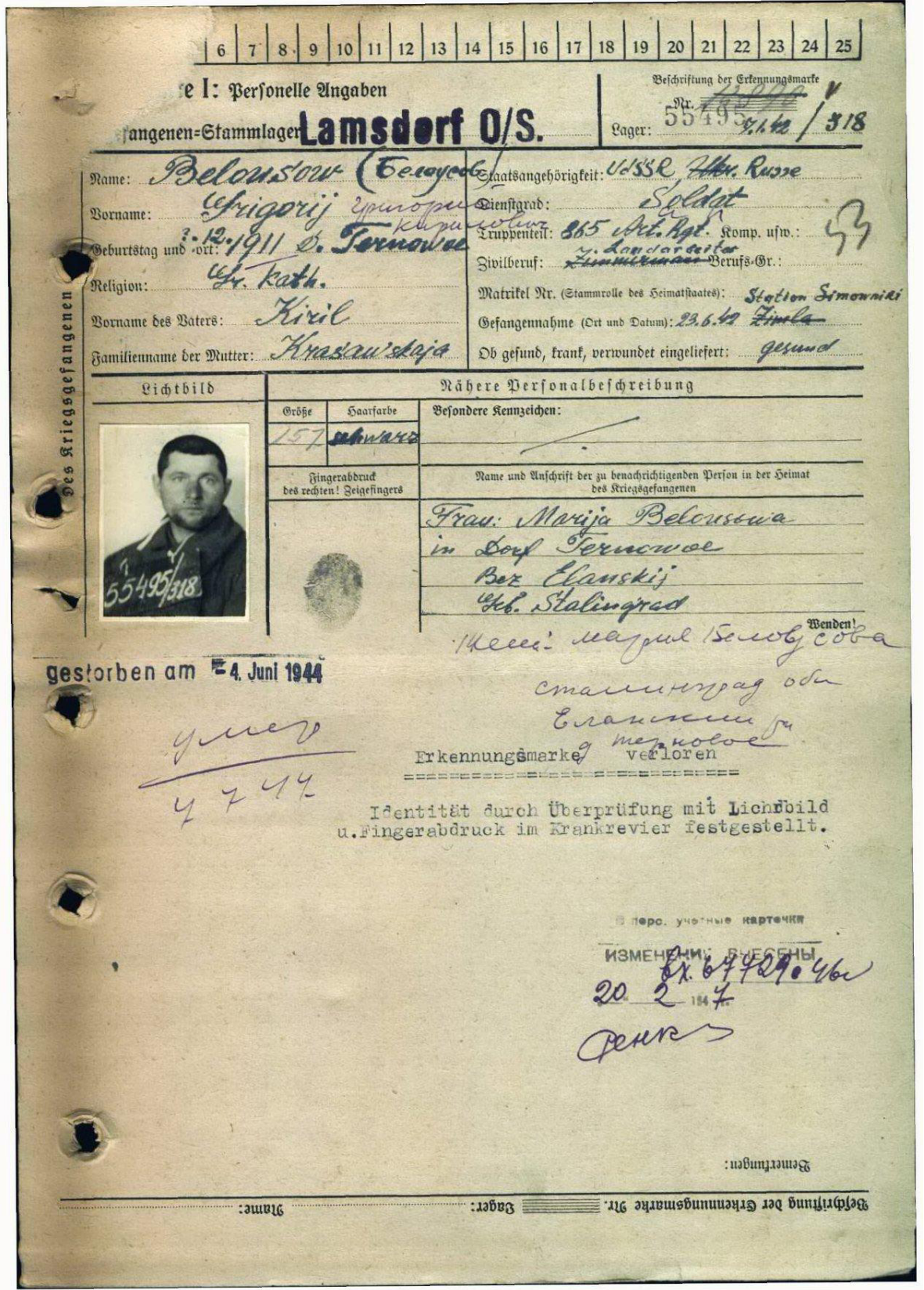

Ryc. 1-2. Awers i rewers karty obozowej sowieckiego jeńca wojennego Grigorija Bielousowa, nr jeniecki 55495, jeńca Stalagów 318/VIII F Lamsdorf i 344 Lamsdorf. Został wzięty do niewoli 23 maja 1942 r. w Simownikach (obwód rostowski), stamtąd odesłany został do Lamsdorf, a następnie 11 grudnia 1942 r. do komanda pracy R 798 w Królewskiej Hucie (Königshütte, obecnie 


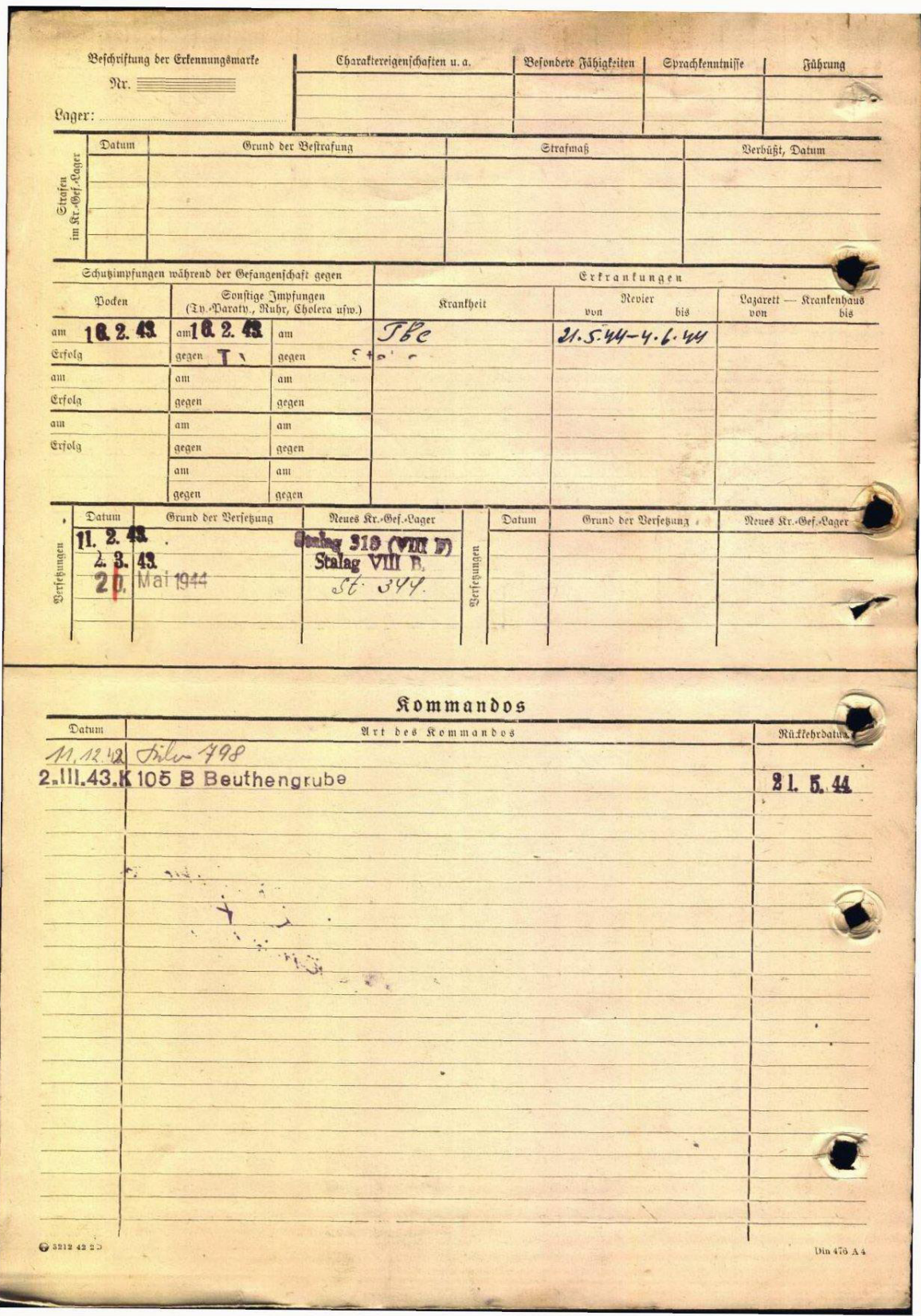

Chorzów), realizującego prace porządkowe. 2 marca 1943 r. przeniesiony został do komanda roboczego R 105 przy kopalni „Beuthengrube”. 21 maja 1944 r. odesłano go do obozu macierzystego w Lamsdorf, gdzie zmarł z powodu gruźlicy 23 czerwca 1944 r. (zbiory własne). 
utworzono w kopalni również komando dla internowanych żołnierzy włoskich - It $21^{41}$. W czasie wizytacji komanda przez władze obozowe, w marcu 1943 r., informowano, że spora liczba mężczyzn chorowała. Doskwierał brak żywności, a regulaminowe posiłki otrzymywali tylko ci jeńcy, którzy pracowali w systemie zmianowym w ciągu dnia ${ }^{42}$.

\subsection{Komanda R 100 i R 657. Kopalnia „Heinitz”43}

Została utworzona w 1856 r. W 1883 r. przyłączono do niej pola Rossberg, Nanny i Moritz, będące w posiadaniu Ottona Friedländera. Sprzedano je podczas licytacji, za długi. W 1890 r. zostały wykupione przez koncern Georg von Giesches Erben (Bergwerksgesellschaft Georg von Giesche’s Erben AG). Począwszy od 1922 r. część pola stanowiła samodzielną jednostkę, znalazła się po stronie polskiej. W czasie wojny kopalnia wchodziła w skład koncernu Zakłady „Herman Göring”.

Baraki obozowe zlokalizowano przy szybie „Barbara” (Barbaraschacht). W kopalni funkcjonowały dwa komanda dla jeńców sowieckich - R 100 i R 657. Osadzonych nadzorowało średnio 13-15 żołnierzy niemieckich.

${ }^{41} \mathrm{Na}$ mocy rozporządzenia Adolfa Hitlera z 31 VIII 1944 r. dokonano masowych zwolnień internowanych żołnierzy włoskich, po dobrowolnym podpisaniu przez nich dokumentów, w których wyrażali zgodę na zmianę statusu na cywilnego pracownika przymusowego, a tym samym na pozostanie na terenie III Rzeszy i dalszego świadczenia pracy. Ci, którzy dopełnili formalności, nie podlegali odtąd administracji obozu macierzystego w Lamsdorf. Docelowo byli przekazywani do dyspozycji urzędów pracy. Zwolnienia odmówiono oficerom oraz żołnierzom określanym jako tzw. element niepewny politycznie oraz tym, którzy nie podpisali wspomnianej deklaracji. W większości zwolnienia internowanych żołnierzy włoskich z niewoli miały wymiar formalny, pozostawiono ich bowiem w tych samych miejscach pracy. Jednak nie przysługiwały im już przywileje, głównie paczki pomocowe, z jakich korzystali jeńcy brytyjscy czy francuscy. Stalagowi VIII B Teschen podlegały wówczas, czyli w 1944 r., 42 komanda pracy dla internowanych żołnierzy włoskich na Górnym Śląsku (Z. KoneČnY, F. Mainuš, op. cit., s. 74).

42 ACMJW, Mikrofilmy, Mikrofilm praski, 2-II-R, nr skanu 321, 340, 348, 380, 431-432, 437, 634; MiD. Statystyka Genewska, sygn. 2, k. 30; APK, 703, sygn. 200, Kriegsgefangene (19401944), k. 99 (19 VIII 1942); Archives du Comité international de la Croix-Rouge (dalej: Archives du CICR), Stalag VIII B Teschen (26 VIII 1944), k. 8; S. SENFT, H. WiĘCEK, op. cit., s. 55; J. JAROS, Stownik historyczny kopalń wegla na ziemiach polskich, Katowice 1984, s. 33; Obozy hitlerowskie na ziemiach polskich 1939-1945. Informator encyklopedyczny, red. Cz. PILICHOwsKi i in., Warszawa 1979, s. 124-125; Z. KonEČNY, F. MAínUš, op. cit., s. 66, 104, 106.

43 Po wojnie „Rozbark”, obecnie nie istnieje. 
W sprawozdaniach wizytacyjnych władz obozowych z lat 1943-1944 informowano lakonicznie, jednozdaniowo, na temat warunków zakwaterowania i wyżywienia w obydwu komandach. W komandzie R 657 dochodziło do licznych przypadków okaleczeń palców rąk i nóg ${ }^{44}$. Iwan Pantelejmonowicz Chabenko, jeniec z komanda R 100, relacjonowat:

Wysłano nas do Wołszańska, obwód swierdłowski (Federacja Rosyjska), a po trzech dniach do Równego (Stalag 360), na terenie zachodniej Ukrainy. Znajdował się tam obóz dla jeńców wojennych. Po miesiącu przeniesiono nas do Niemiec, do Lamsdorf (Stalag VIII B/318 Lamsdorf). Pod koniec jesieni 1942 r. zostałem odtransportowany do Bytomia. Znajdowała się tam kopalnia. Jedzenie było bardzo złe. Dwa razy dziennie dostawałem litr zupy z brukwi i 400 gram chleba z odpadami. W pierwszej grupie przybyło do kopalni 300 jeńców. Ja przybyłem z drugą grupą. W wyniku upodlenia, głodu i niewolniczej pracy z całej grupy przy życiu pozostało zaledwie 50. Pracowaliśmy w kopalni od końca 1942 r. do 1944 r. Szyby miały 774 i 885 metrów głębokości. Przeżyłem dzięki pomocy Polaków, którzy dawali mi coś do jedzenia ${ }^{45}$.

Liczba jeńców w kopalni „Heinitz” zwiększała się systematycznie w latach 1942-1944. Najliczniejsze transporty przybyły w listopadzie 1942 r. - 100 jeńców oraz w sierpniu 1943 r. - 109 jeńców. Według sprawozdania z 10 stycznia 1944 r. w barakach obozowych przebywało łącznie 1348 jeńców, zaś według sprawozdania z 8 lutego 1944 r. 1226 mężczyzn. Rotacja wśród osadzonych była znacząca, aczkolwiek nieregularna. W $1942 \mathrm{r}$. w kopalni rozpoczęło pracę 260 jeńców, w 1943 r. zatrudniano 429 mężczyzn, w tym trzech jeńców francuskich. Przeniesiono wówczas, do obozu macierzystego lub do innych komand roboczych, 47 jeńców radzieckich. W 1944 r. przybyło w transportach łącznie 130 jeńców, natomiast 180 przeniesiono do innych komand, w okolicznych zakładach przemysłowych. W styczniu 1945 r., przed ewakuacją, komando R 100 liczyło 293 mężczyzn, natomiast R 657 - 225 jeńców (Tabela 2) ${ }^{46}$.

${ }_{44}$ APK, 703, sygn. 200, Kriegsgefangene (1940-1944), k. 91; VHA, 3360/1/63 (cały poszyt dotyczy poborów członków nadzoru komand R 100, R 101 i R 657); ACMJW, Mikrofilmy, Mikrofilm praski, 2-R-II, nr skanu 321, 340, 431; J. Jaros, op. cit., s. 91; Z. KONEČny, F. MaInuš, op. cit., s. 106; Obozy hitlerowskie..., s. 124-125.

45 ACMJW, Relacje i Wspomnienia, sygn. 34, Iwan Pantelejmonowicz Chabenko, k. 1.

${ }^{46}$ APK, 703, sygn. 200, Kriegsgefangene (1940-1944), k. 108, 110. 
Tabela 2

Transporty jeńców radzieckich do kopalni „Heinitz” (1942-1944)

\begin{tabular}{|c|c|c|}
\hline Czas & Liczba przybyłych jeńców & $\begin{array}{l}\text { Liczba przeniesionych } \\
\text { jeńców }\end{array}$ \\
\hline 26 października 1942 & 50 & - \\
\hline 27 października 1942 & 60 & - \\
\hline 30 października 1942 & 50 & - \\
\hline 26 września 1942 & 100 & - \\
\hline 6 stycznia 1943 & 50 & 47 \\
\hline 4 marca 1943 & 30 & - \\
\hline 9 marca 1943 & $3^{*}$ & - \\
\hline 17 sierpnia 1943 & 109 & - \\
\hline 1 września 1943 & 50 & - \\
\hline 10 września 1943 & 15 & - \\
\hline 20 września 1943 & 55 & - \\
\hline 17 października 1943 & 50 & - \\
\hline 12 grudnia 1943 & 67 & - \\
\hline 11 stycznia 1944 & 1 & 58 \\
\hline 8 lutego 1944 & - & 122 \\
\hline 17 lutego 1944 & 22 & - \\
\hline 28 lutego 1944 & 67 & - \\
\hline 27 lipca 1944 & 40 & - \\
\hline 23 sierpnia 1944 & 10 & - \\
\hline
\end{tabular}

* Jeńcy francuscy

Źródło: APK, 703, sygn. 200, Kriegsgefangene (1940-1944), k. 108-201, 223.

\subsection{Komando robocze R 101}

Kopalnia „Karsten-Zentrum-Grube” ${ }^{\text {47 }}$ powstała 1 grudnia 1881 r. z połączenia kopalń i pól górniczych: Karsten, Zentrum, konsorcjum Beuthener Gruben oraz Kaiser Wilhelm pod nazwą Vereinigte Karsten-Zentrum. Do 1879 r.

\footnotetext{
47 Po wojnie kopalnia „Centrum”, „Dymitrow”, obecnie nie isnieje.
} 
należała do koncernu Schlesische A.G. für Bergbau und Zinkhüttenbetrieb, od 1922 r. zaś do Schlesische Bergwerks- und Hütten A.G.

W czasie II wojny światowej w kopalni „Karsten-Zentrum-Grube” zatrudniano jeńców sowieckich. Nadzór nad nimi pełniło ok. 25-29 żołnierzy niemieckich $^{48}$. Od momentu przybycia pierwszego transportu latem 1942 r. ich liczba zwiększała się dynamicznie w kolejnych dwóch latach (1942-1943). Jeńcy sowieccy, ok. 400 mężczyzn, przybyli do Bytomia ze stalagu w Lamsdorf 30 lipca 1942 r. Weszli w skład komanda R 101. Zakwaterowano ich w barakach przy obecnej ulicy Łużyckiej, w obozie nr 1 (Lager 1), wcześniej wykorzystywanym jako areszt policyjny (Polizeilager) oraz w barakach bezpośrednio przy kopalni (Lager 2). Przywożonych standardowo poddawano badaniom i odrobaczaniu. 3 sierpnia 1942 r. pierwszych przybyłych zatrudniono w kopalni. W celu zapobiegania wypadkom przydzielano im proste i nieskomplikowane prace, uniemożliwiając tym samym ewentualne akty sabotażu. Zatrudniani byli w charakterze: taśmowych, ładowaczy, strzałowych, obsługujących pompy, konserwatorów maszyn i urządzeń, elektryków, ponadto również przy robotach strzałowych, transporcie i wydawaniu materiałów wybuchowych ${ }^{49}$. Osadzeni podlegali nadzorowi ze strony wykwalifikowanych majstrów-sztygarów. Trudności z jednej strony z koniecznością sprostania wymogom niemieckiej gospodarki wojennej, z drugiej zaś brakom kadrowym w odniesieniu do robotników wykwalifikowanych, były powodem licznych problemów między kierownictwem a jeńcami. Dochodziły do tego również problemy komunikacyjne, wypadki spowodowane nieznajomością górniczej sztuki, akcjami sabotażowymi, a w wielu wypadkach wycieńczeniem jeńców. Mikołaj Miagkich, jeniec sowiecki, relacjonował:

W czasie pracy w kopalni byliśmy nielitościwie bici przez Niemców i dozorców - Polaków, głównie za to, że nie rozumieliśmy języka niemieckiego i że wolno pracowaliśmy. Takie zdarzenia nie tylko widziałem, ale doświadczyłem ich osobiście, niejednokrotnie zostałem uderzony przez mojego majstra - Niemca nazwiskiem Malik. Systematycznie bił jeńców również drugi z majstrów - Niemiec nazwiskiem Kowyl. W rezultacie nieludzkiego traktowania - systematycznego bicia i piekielnie ciężkiej fizycznej pracy, przy jednoczesnym braku odpowiedniego wyżywienia - wielu z moich towarzyszy, szczególnie tych, którzy pracowali na powierzchni, podejmowało

${ }^{48}$ VÚA, 3360/1/63 (cały poszyt, dotyczy poborów członków nadzoru komand R 100, R 101 i R 657).

49 APK, 703, sygn. 200, Kriegsgefangene (1940-1944), k. 95 (Beuthen, Carsten-Zentrum-Grube, 10 VIII 1942). 


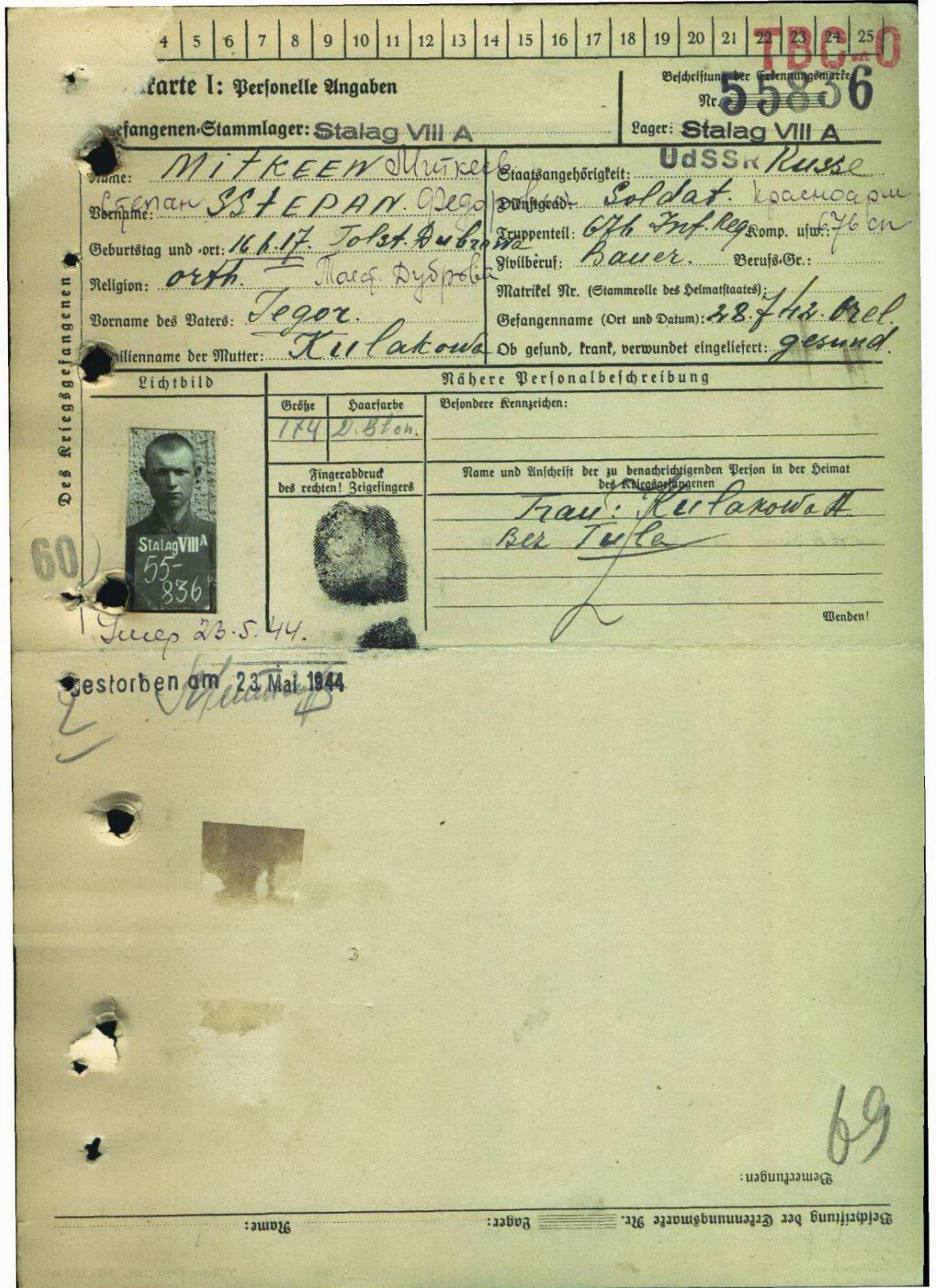

Ryc. 3-4. Awers i rewers karty obozowej sowieckiego jeńca wojennego Stepana Mitkina, nr jeniecki 55836, jeńca Stalagów VIII A Görlitz, 318/VIII F Lamsdorf i 344 Lamsdorf. Został wzięty do niewoli 28 VII 1942 r. do Görlitz. 2 września 1943 r. przeniesiono go do Lamsdorf, skąd 18 IX 


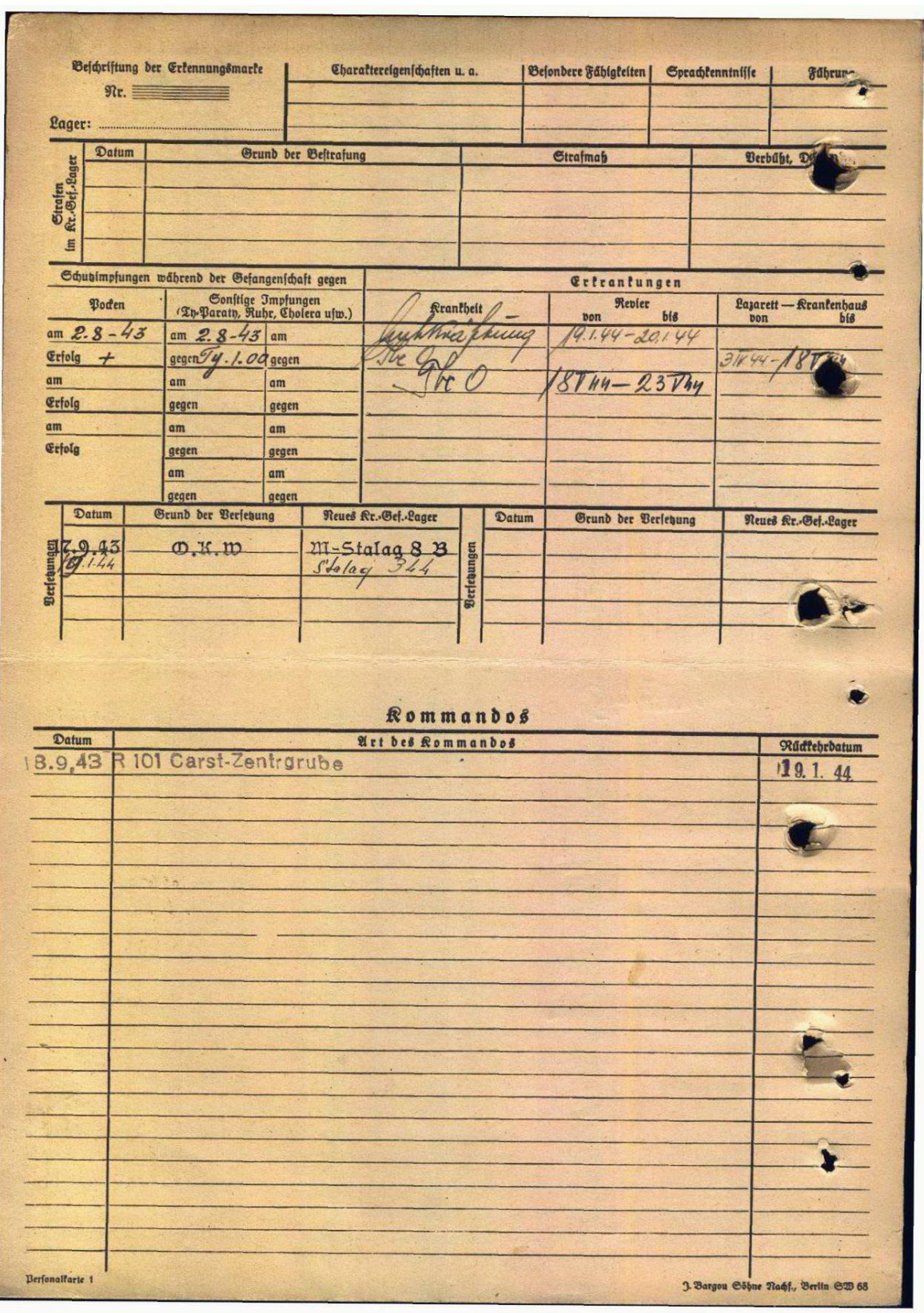

1943 r. trafił do komanda pracy R 105 w Bytomiu przy kopalni „Carsten-Centrum”. 19 I 1944 r. odesłano go do obozu macierzystego w Lamsdorf, gdzie 23 V 1944 zmarł z powodu gruźlicy (ze zbiorów własnych). 
próby ucieczki. Wielu z nich Niemcy aresztowali i odsyłali z powrotem do obozu. Uciekinierów karano biciem, dziennie po 25 batów rano i wieczorem przez cały tydzień. Oprócz bicia uciekinier przez 7 dni otrzymywał zmniejszone o $50 \%$ racje żywnościowe. Po tygodniu udręki musieliśmy niejednokrotnie uciekiniera prowadzić pod rękę, aby nie upadł, bo groziła mu w przeciwnym razie śmierć. Zdarzały się przypadki, że niektórzy nie wytrzymywali tortur. Odsyłano ich potem do obozu w Lamsdorf. W roku 1944 w związku z przybliżaniem się frontu Niemcy ogłosili, że za ucieczkę będą rozstrzeliwać i rzeczywiście z końcem maja i na początku czerwca 1944 r. za ucieczkę rozstrzelano 7 osób (...). Egzekucji dokonał sam komendant ${ }^{50}$.

W sprawozdaniu Urzędu Górniczego Bytom-Północ z 7 maja 1943 r. odnotowano, że w kopalni pracowało wówczas 965 jeńców radzieckich. 9 grudnia 1943 r. wzmiankowano 1405 mężczyzn. Zachowały się sprawozdania do sierpnia 1944 r. włącznie. Do tego czasu liczba jeńców zatrudnionych w kopalni utrzymywała się na stałym poziomie, tj. 1200-1300 mężczyzn. Rotacja była znacząca. Transporty przybywających do pracy w kopalni „Karsten-Zentrum-Grube” były zróżnicowane pod względem liczebnym. Pomijając jednostkowe przeniesienia, liczba ta wynosiła od kilkudziesięciu do nawet kilkuset jeńców w transporcie. Najliczniejsze pojedyncze transporty jeńców sowieckich przybyły do Bytomia we wrześniu 1942 r. - 400 mężczyzn i w październiku 1943 r. - 584 mężczyzn. W 1942 r. przywieziono łącznie 735 jeńców, a w 1943 r. - 1399. Przeniesiono lub odesłano do obozu macierzystego, zazwyczaj z przyczyn zdrowotnych i wycieńczenia - 649 mężczyzn. Przeciętnie transporty następowały raz w miesiącu (Tabela 3). W sprawozdaniach kontrolnych władz obozowych w Lamsdorf pojawiały się adnotacje o skargach jeńców na przypadki maltretowania fizycznego, poprzez zwiększenie liczby godzin pracy do dwunastu na dobę, braku odzieży roboczej oraz zaniżania racji żywnościowych. Do kasy kopalni, tytułem utrzymania jeńców, wpływało co miesiąc ok. 15000 marek. W listopadzie 1944 r. w komandzie R 101 pracowało 1056 jeńców sowieckich, w grudniu 1138, natomiast w styczniu 1945 r., tuż przed ewakuacją, 1036 mężczyzn ${ }^{51}$.

50 ACMJW, Relacje i Wspomnienia, sygn. 27, Mikołaj Miagkich, k. 3. Mikołaj Miagkich ur. 1922 r. we wsi Niżne Olszane w rejonie Dołżańskim. W Armii Czerwonej służył od grudnia 1941 r. do 26 V 1942 r., w 248 oddzielnej kompanii chemicznej, w charakterze chemika. W maju 1942 r. został wzięty do niewoli podczas oblężenia wioski Zielony Ług. Etapami, przez Pawłograd i Sławutę, transportem kolejowym, został przywieziony, z grupą ok. 500 jeńców sowieckich, do Stalagu 318/ VIII F Lamsdorf, gdzie trafił 15 VII 1942 r. Osadzonych rozmieszczono na placu nieopodal przepetnionych baraków. Do komanda R 101 przewieziono go 17 VIII 1942 r.

51 APK, 703, sygn. 200, k. 109-210; VÚA, 503/1/101, b.p.; ACMJW, Mikrofilmy, Mikrofilm praski, 2-R-II, nr skanu 321, 340, 432, 530; J. Jaros, op. cit., s. 39; Obozy bitlerowskie..., s. 124. 
Tabela 3

\section{Transporty jeńców radzieckich do kopalni „Karsten-Zentrum-Grube” (1942-1944)}

\begin{tabular}{|c|c|c|}
\hline Data & Liczba przybyłych jeńców & Liczba przeniesionych jeńców \\
\hline 15 września 1942 & 200 & - \\
\hline 30 września 1942 & 400 & - \\
\hline 23 października 1942 & 134 & - \\
\hline 11 grudnia 1942 & 1 & - \\
\hline 12 stycznia 1943 & 1 & - \\
\hline 28 stycznia 1943 & 75 & - \\
\hline 5 lutego 1943 & 7 & - \\
\hline 5 marca 1943 & 50 & - \\
\hline 8 kwietania 1943 & 80 & - \\
\hline 7 maja 1943 & 16 & 370 \\
\hline 2 czerwca 1943 & - & 56 \\
\hline 15 czerwca 1943 & 40 & - \\
\hline 30 czerwca 1943 & 40 & - \\
\hline 1 lipca 1943 & - & 23 \\
\hline 3 sierpnia 1943 & - & 85 \\
\hline 19 września 1943 & 120 & - \\
\hline 5 października 1943 & 584 & 42 \\
\hline 2 listopada 1943 & 286 & 39 \\
\hline 9 grudnia 1943 & 100 & 34 \\
\hline 5 marca 1944 & - & 60 \\
\hline 6 marca 1944 & 100 & - \\
\hline 4 kwietnia 1944 & 51 & 3 \\
\hline 6 maja 1944 & 3 & 47 \\
\hline 5 czerwca 1944 & 36 & 20 \\
\hline 5 lipca 1944 & 5 & 77 \\
\hline 8 sierpnia 1944 & 1 & 37 \\
\hline 23 sierpnia 1944 & 10 & - \\
\hline
\end{tabular}

Źródło: APK, 703, sygn. 200, Kriegsgefangene (1940-1944), k. 109-210, 224. 
Rytm dnia w komandzie wyznaczały posiłki i praca. Trudne warunki bytowe i żywieniowe były powodem licznych chorób, a nadludzka praca wycieńczenia organizmu. Jeniecką codzienność w komandzie R 101 opisywał Mikołaj Miagkich:

W obozie [w Stalagu 318/VIII F Lamsdorf - dop. J.L.] byłem do 17 września 1942 r., po czym z oddziałem nr 101, składającym się ze 150 jeńców, zostałem przetransportowany do kopalni w mieście Bytomiu (...). Pamiętam dobrze, że w ciągu miesięcznej pracy w kopalni z naszego oddziału pozostało tylko 40 ludzi, zaś 110 jako wycieńczonych i niezdolnych do pracy odesłano z powrotem do obozu. $\mathrm{Z}$ tej liczby 3-4 zmarło w barakach przy kopalni. Wyżywienie było bardzo liche: zupa z brukwi i trawy oraz 400 g chleba na dobę. Wskutek tego ludzie chudli, chorowali na żołądki (biegunka) i padali bezsilni podczas pracy i z tego powodu odwożono ich z powrotem do obozu, skąd w zamian przywozili bardziej zdrowych ludzi. Wymiana chorych na zdrowszych odbywała się nieraz 2-3 razy w miesiącu, niedużymi partiami po 35-60 ludzi. Pod koniec wojny partie te były znacznie większe, sięgając 100-350 ludzi ${ }^{52}$.

Jeńcy sowieccy z komanda R 101 mieli zapewnioną, co należało do rzadkości, opiekę medyczną ze strony sowieckiego lekarza - jeńca Alexeja Anochina. Wrócił do obozu macierzystego, tj. Stalagu VIII B Teschen zgodnie z rozkazem władz z 11 stycznia $1944 \mathrm{r}^{53}$

Osadzeni pracowali w kopalni wespół z robotnikami niemieckimi. Niejednokrotnie władze niemieckie korzystały z usług szpiegów, celem pozyskiwania informacji o planowanych akcjach sabotażowych, przyczynach spadku wydajności czy zwiększaniu się odsetka wypadków. Również do komanda R 101 wprowadzono szpiega, odnotowano:

W kopalni w Bytomiu zatrudniony jest na polskiej zmianie polski robotnik Franz, który mówi po niemiecku i francusku. Posiada on bardzo mały, ale sprawny radioodbiornik, za pomocą którego słucha wrogich audycji, a ich treść przekazuje jeńcom z oddziału R 101. Podżega w ten sposób jeńców do działalności antyniemieckiej ${ }^{54}$.

Mikołaj Miagkich wspominał o licznych przypadkach karania jeńców sowieckich oraz wymyślnych sposobach torturowania, odzierających ich z resztek człowieczeństwa. Relacjonował:

\footnotetext{
52 ACMJW, Relacje i Wspomnienia, sygn. 27, Mikołaj Miagkich, k. 2.

53 VÚA, 795/1/193, karty bez paginacji.

${ }^{54}$ Z. KoneČnY, F. Mainuš, op. cit., s. 98.
} 
W obozie przy kopalni karali za byle co. Za niepozdrowienie Niemców, karali, jeśli coś wypadło z kieszeni, karali za wszystko, do czego się można było przyczepić, bo nas nienawidzili. Pozbawiali nas zupy, wsadzali do bunkra i bili plecionkami. Był jeszcze inny sposób kary: winowajcy kazali stanąć na krzesło między ogrodzeniem z drutu, ręce podnieść w górę i w takiej pozycji stać 8 godzin ${ }^{55}$.

23 czerwca 1944 r. władze niemieckie dokonały odkrycia aktu sabotażu w kopalni „Heinitz”. Podczas kontroli osobistej w barakach jeńców okolicznych komand, w tym zajmowanych przez jeńców sowieckich komanda R 101, znaleziono detonatory zapalające. 1 lipca 1944 r. akt sabotażu został opisany ze szczegółami w sprawozdaniu Urzędu Górniczego Bytom-Północ i przedstawiony władzom rejencji w Katowicach i władzom VIII OKW we Wrocławiu. Podczas śledztwa ustalono, że przy konstrukcji detonatorów wykorzystano materiały wybuchowe dostępne w kopalni, przemycone w pędzlu do golenia. Wskazano również winnego - jeńca Nikolaia Muchina. 24 lipca1944 r., na mocy postanowienia sądu wojennego, jeniec ów, podlegający administracyjnie Stalagowi VIII B Teschen, został przekazany Gestapo. Jego losy pozostają nieznane ${ }^{56}$. W kopalni „Karsten-Zentrum-Grube” odnotowywano, zresztą podobnie jak i w innych kopalniach, wypadki śmiertelne. W sprawozdaniach rocznych od kwietnia 1943 r. do marca 1944 r. Urzędu Górniczego Bytom-Północ podawano liczbę ośmiu jeńców radzieckich ${ }^{57}$.

\subsection{Komando robocze E 490}

Jeńców wykorzystywano również do prac murarskich - komando jeńców brytyjskich E 490 funkcjonowało w Bytomiu, w zakładzie „Eisenbeton und Hochbau” mistrza murarskiego Roberta Matusska, przy obecnej ulicy Stanisława Witczaka (Scharleyerstraße 110), który wykonywał konstrukcje żelbetonowe na potrzeby budownictwa. W sprawozdaniach władz obozowych podkreślano, że jeńcy nie dysponowali właściwą odzieżą roboczą. W komandzie przebywało średnio ok. 25-35 Brytyjczyków. Byli nadzorowani przez 2-3 żołnierzy niemieckich. W sierpniu 1944 r. komando podlegało wizytacji przedstawicieli

\footnotetext{
55 ACMJW, Relacje i Wspomnienia, sygn. 27, Mikołaj Miagkich, k. 2.

${ }^{56}$ APK, 703, sygn. 355, k. 98-101, 110-112.

57 APK, 703, sygn. 200, k. 109-210.
} 
MKCK. Zatrudnionych w nim było wówczas 27 mężczyzn. Funkcję męża zaufania sprawował sierż. Robert Gill ${ }^{58}$. Tytułem zapłaty za jeńców Robert Matussek otrzymywał miesięcznie wynagrodzenie ok. 1500 marek. W styczniu 1945 r. oddział liczył 32 osoby ${ }^{59}$.

W lakonicznej notatce, zawartej w sprawozdaniu z wizytacji Stalagu VIII B Teschen z 17 września 1944 r., donoszono na temat warunków panujących w komandzie:

Bytom. Komando E 490 obsługuje tylko jeden sanitariusz. Dwa razy w ciągu tygodnia chorzy jeńcy są badani w lazarecie rezerwy w Bytomiu. Podstawową opiekę stomatologiczną zapewnia cywilny lekarz, na pozostałe zabiegi jeńcy są kierowani do stalagu w Lamsdorf. Ogólny stan komanda robi dobre wrażenie. Zarówno pod względem środków materialnych, jak też opieki jest on zadowalający ${ }^{60}$.

Komando robocze R 914. Jeńcy sowieccy pracowali również w koszarach, w bazie sił powietrznych VIII Okręgu Wojskowego Wehrmachtu (Luftgau-Kommando VIII) ${ }^{61}$. Brak jednak jakichkolwiek informacji na temat świadczonej przez nich pracy.

\section{Kursy języka niemieckiego dla jeńców wojennych}

We wrześniu 1943 r. władze Urzędów Górniczych, którym podlegały bytomskie kopalnie, wespół z władzami obozowymi, podjęły decyzję o zorganizowaniu dla jeńców sowieckich oraz cywilnych pracowników przymusowych zatrudnionych w zakładach przemysłowych kursów języka niemieckiego. Nad prowadzeniem przedsięwzięcia czuwać miał nadzór komand, w których zajęcia prowadzono, te zaś miały być realizowane przez wykwalifikowanych specjalistów. Celem zajęć było zapewnienie lepszej komunikacji między

58 ACMJW, MiD. Statystyka Genewska, sygn. 2, k. 30; The National Archives (dalej: TNA), FO 916/1150, Sprawozdanie z wizytacji z 26 VIII 1944 r., k. 5; ACMJW, Mikrofilmy, Mikrofilm praski, 2-R-II, nr skanu 340, 431; Archives du CICR, Stalag VIII B Teschen (26 VIII 1944), k. 8; Obozy hitlerowskie..., s. 124.

59 VÚA, 501/1/101, k. 8-12; 365/1/65 (poszyt dotyczy poborów członków nadzoru komanda E 490).

${ }^{60}$ TNA, FO 916/1150, Sprawozdanie z 17 I 1945 r. Stalag VIII B Teschen, k. 14.

${ }^{61}$ ACMJW, Mikrofilmy, Mikrofilm praski, 2-R-II, nr skanu 340. 
załogą, a pracownikami przymusowymi i jeńcami, jak również z nadzorem w komandzie ${ }^{62}$.

Przed rozpoczęciem kursów w poszczególnych komandach należało przygotować pomieszczenia dla 30-40 osób, tj. wyposażone w tablice ścienne oraz wystarczające oświetlenie i możliwością ogrzewania w zimie. Kursy miały być prowadzone w godzinach 8.00-11.00 przed południem oraz 17.00-19.00. Program zakładał naukę języka niemieckiego w mowie i piśmie (Erlernung der deutsche Sprache), zapoznanie kursantów ze słownictwem z kręgów tematycznych tj. człowiek (Mensch), mieszkanie (Wohnung), obóz (Lager) oraz zakład pracy (Betrieb). Poznając słownictwo odnoszące się do zakładu pracy koncentrowano się na opanowaniu słownictwa związanego z zapobieganiem wypadkom oraz teorią i praktyką wykonywanej pracy. Dzięki wprowadzonemu systemowi na bieżąco zamierzano monitorować postępy w nauce ${ }^{63}$. Dominowały metody poglądowe, z wykorzystaniem praktycznej demonstracji maszyn i narzędzi, których elementarna znajomość miała przynajmniej w jakimś stopniu wyeliminować wysoki wskaźnik wypadkowości w kopalni. Wykorzystywano plansze szkoleniowe ze schematami, plansze z zakresu udzielania pierwszej pomocy i modele dla szkół górniczych. Kursanci korzystali z książki wydanej przez Ferdinanda Hirta Betriebswirtschaftslehre, w opracowaniu G.A. Gloecknera (Leipzig 1942), przede wszystkim przyswajano słownictwo zawarte w rozdziale piątym, tj. szkoła górnicza i warsztaty (die Bergberufsschule und die Berglehrwerkstatt) oraz słownictwo zawodowe (w ślusarni, u kowala, naprawa maszyn górniczych, w warsztacie, w tartaku, zawód górnika, wymagania i obowiązki, zjazd w kopalni, górnictwo ścianowe, tunele, wydobycie węgla $)^{64}$.

${ }^{62}$ APK, 711, Gräflich Schafgotsche Werke. Kopalnia Hohenzollern w Szombierkach, sygn. 69, Deutschkurse (1943), k. 2 (Beuthen, Hohenzollerngrube, 11 IX 1943, betr. Gestaltung der Lagerführung bei der Betriebsgruppe Hohenzollern).

${ }_{63}$ APK, 711, sygn. 69, k. 3-7 (Beuthen, Hohenzollerngrube, 23 września 1943, Unterricht der fremdländischen Arbeiter und der Kgf. zur Erlernung der deutschen Sprache der Betriebsgruppe Hohenzollern).

${ }^{64}$ APK, 711, sygn. 69, k. 13-46. 


\section{Warunki zakwaterowania}

Jeńcy kwaterowani byli zazwyczaj w barakach znajdujących się w pobliżu miejsca pracy. Ich stały napływ spowodował konieczność poszukiwania doraźnych miejsc zakwaterowania. W latach 1940-1944 w powiecie bytomskim/bytomsko-tarnogórskim miejskim i ziemskim utworzono kilkanaście zbiorczych obozów pracy przymusowej (Gemeinschaftslager), w których poza cywilnymi pracownikami przymusowymi kwaterowano również jeńców ze stalagów w Lamsdorf i Teschen. Dla powiatu miejskiego prowadzono siedem obozów zbiorczych ${ }^{65}$. Należały do nich trzy obozy dla jeńców pracujących w zakładach wchodzących w skład koncernu Georga von Gieschego, m.in. kopalni „Heinitz”. Funkcjonowały przy ulicach Siemianowickiej (Laurahütter-Landstraße 74), Jagiellońskiej (Hohenzollernstraße 27) i Alojzjanów (Elsterbergstraße 27). Ponadto osadzonych z komand roboczych kwaterowano w dwóch obozach zbiorczych dla jeńców z kopalni „Karsten-Zentrum”, które znajdował się przy ulicy Łużyckiej (Saarlandstraße) oraz dwóch obozach zbiorczych dla jeńców z kopalni „Beuthen”, zlokalizowanych przy ulicy Strzelców Bytomskich (Ostlandstraße 89). W powiecie bytomskim/bytomsko-tarnogórskim ziemskim prowadzono jedenaście obozów zbiorczych, w tym sześć dla jeńców z zakładów przemysłu ciężkiego, które znajdowały się w bezpośrednim sąsiedztwie miasta ${ }^{66}$.

\section{Podsumowanie. Ewakuacja i wyzwolenie}

Decyzja o ewakuacji jeńców wojennych i cywilnych pracowników przymusowych z Górnego Śląska i Zagłębia Ostrawsko-Karwińskiego w głąb Rzeszy zapadła późną jesienią 1944 r. Była ona podyktowana realną oceną sytuacji na froncie wschodnim. Powzięcie procedury ewakuacji jeńców wojennych z Górnego Śląska (tzw. U-Plan, kryptonim KREBS) było zgodne z zapisami konwencji genewskiej z 1929 r., w której określono, że jeniec nie może być narażony na przebywanie w strefie działań wojennych. Plany te nie wynikały bynajmniej ze względów humanitarnych, a raczej z potrzeby maksymalnej eksploatacji pracowników przymusowych. W przypadku jeńców chodziło

\footnotetext{
${ }^{65}$ APK, 704, sygn. 93, Ausländer (1940-1944), k. 154.

${ }^{66}$ APK, 704, sygn. 93, k. 155.
} 
ponadto o niedopuszczenie do wyzwolenia przez armie własne lub sojusznicze i ich ewentualnego powrotu do regularnej służby. Władze rejencji katowickiej wydały odpowiednie rozporządzenie 21 grudnia $1944 \mathrm{r}^{67} \mathrm{~W}$ styczniu $1945 \mathrm{r}$. w komandach roboczych powiatu bytomsko-tarnogórskiego miejskiego i ziemskiego przebywało łącznie 9600 jeńców $^{68}$.

Jeńcy podlegli Stalagowi VIII B Teschen, w tym ci przebywający w komandach pracy w Bytomiu, mieli się przemieszczać pieszo, wytyczoną wcześniej trasą, tj. w kierunku Stalagu 344 Lamsdorf, następnie zaś Stalagów VIII A Görlitz i VIII C Sagan lub przez Protektorat Czech i Moraw na południe. Punkty docelowe stanowić miały obozy jenieckie zlokalizowane w Turyngii i Hesji (IX Okręg Wojskowy) oraz Bawarii (XIII Okręg Wojskowy). Ewakuację ze Stalagów VIII B Teschen i344 Lamsdorf prowadzono w ekstremalnych warunkach, przy temperaturze około $-30 C^{\circ}$. Jeńcom brakowało żywności i odpowiednich ubrań. Średnie dzienne tempo marszu wynosiło $15-20 \mathrm{~km}$. Noce spędzali w barakach, które opuścili już inni osadzeni, szkołach, budynkach użyteczności publicznej, stodołach, halach fabrycznych, nierzadko również pod gołym niebem ${ }^{69}$. Wielu jeńców zmarło nie doczekawszy wyzwolenia, w takcie pokonywania trasy marszów śmierci.

Baraki zajmowane przez osadzonych tymczasowo opustoszały. W miarę instalowania się na terenie Górnego Śląska sowieckiej administracji ponownie się zapełniły. Osadzono w nich ludność uznaną za niemiecką, tworząc sieć obozów pracy, obozów wysiedleńczych i przesiedleńczych, wykorzystywano je również jako warsztaty. Większość baraków zdemontowano w drugiej połowie lat czterdziestych XX w. Drewno i cegły posłużyły do stawiania budynków mieszkalnych i gmachów użyteczności publicznej, częściowo zaś materiały budowlane transportowano do stolicy, wpisując się w proces odbudowy zrujnowanej Warszawy.

67 A. Wickiewicz, op. cit., s. 121-124; J. Lusek, Obozy jenieckie Teschen..., s. 30-31.

${ }^{68}$ VÚA, Stalag VIII B, sygn. 1104/71/D. Poza jeńcami brytyjskimi na terenie powiatu zatrudniani byli jeńcy radzieccy (6485 mężczyzn), jeńcy serbscy (304 mężczyzn), jeńcy belgijscy (156 mężczyzn) i internowani żołnierze włoscy (150 mężczyzn).

69 P. Stanek, Ewakuacja Stalagu VIII B Teschen, [w:] Čas - mista - lidé..., s. 166-175; Z. KoNEČNY, F. MAINUš, op. cit., s. 118-121; H. LAUERWALD, In fremdem Land. Kriegsgefangene im Stalag VIII A Görlitz (1939-1945). Tatsachen, Briefe, Dokumente, Görlitz 1996, s. 77-81; EADEM, Primum viver. Zuerst leben. Wie Gefangenen des Stalags VIII A Görlitz erlebten. Dokumentation und Grundlage mündlicher und schriftlichen Quellen ehemaliger Kriegsgefangener aus Frankreich, Belgien und Italien, Bautzen 2008, s. 114-117. 


\section{BIBLIOGRAFIA}

\section{Źródła archiwalne}

\section{Archives du Comité international de la Croix-Rouge}

Stalag VIII B Teschen.

\section{Archiwum Centralnego Muzeum Jeńców Wojennych}

Materiały i Dokumenty. Kartoteka oddziałów roboczych Stalagu VIII B.

Materiały i Dokumenty. Raporty.

Materiały i Dokumenty. Statystyka Genewska.

Mikrofilmy. Mikrofilm moskiewski.

Mikrofilmy. Mikrofilm praski.

Relacje i Wspomnienia.

\section{Archiwum Państwowe w Katowicach}

Rejencja Katowicka.

Urząd Górniczy Bytom-Południe.

Urząd Górniczy Bytom-Północ.

\section{Bundesarchiv - Militararchiv Freiburg}

Oberkommando der Wehrmacht. Allgemeines Wehrmachtsamt.

\section{The National Archives}

FO 916/1150.

WO 311/1013.

\section{Vojenský ústřední archiv v Praze}

Stalag VIII B.

\section{Opracowania}

Batowski H., Terytorium Śląska w wiekach XIX-XX, zmiany granic i powierzchni 17401950, „Przegląd Zachodni” 1953, t. 3, nr 9/10, s. 351-365.

Boelcke W.A., Die deutsche Wirtschaft 1930-1945. Interna des Reichswirtschaftsministerium, Düsseldorf 1983. 
Bontrup H.-J., Zdrowomyslaw N., Die Deutsche Rüstungsindustrie, Heilbronn 1988.

Bytom i jego dziedzictwo w 750-lecie nadania praw miejskich. Materiaty z interdyscyplinarnej konferencji naukowej w Bytomiu w dniach 18-19 listopada 2004 r.), red. G. Bożek, Katowice 2004.

Čas - mista - lidé. Systém nacistických táborů v letech drubé sveetové války / Czas - miejsca - ludzie. Nazistowski system obozowy w latach drugiej wojny światowej, red. M. Krůl, J. Lusek, Bytom-Český Těšín 2017.

Das Personenlexikon zum Dritten Reich. Wer war was vor und nach 1945, Hrsg. E. Klee, Frankfurt am Main 2005.

Deutsch P., Die oberschlesische Montanindustrie vor und nach der Teilung des Industriebezirks, Bonn 1926.

Die Deutschen, die Zwangsarbeiter und der Krieg. Begleitband zur Ausstellung, Hrsg. V. Knigge, R.G. Luttgenau, J.C. Wagner, Weimar 2010.

Drabina J., Historia Bytomia 1254-2000, Bytom 2000.

Fleming M., Jeńcy wojenni: Studium prawno-historyczne, Warszawa 2000.

Hornig A., Transport wegla, brykietów i koksu na Ślasku w latach 1939-1945, „Zaranie Śląskie" 1963, z. 2, s. 297-305.

Jaros J., Stownik historyczny kopalń wegla na ziemiach polskich, Katowice 1984.

Jędrzejewski E., O niemieckiej administracji na terenach wtaczonych do rejencji opolskiej w latach 1939-1945, „Studia Śląskie” 1969, t. 16, s. 41-76.

Kaczmarek R., Pod rządami gauleiterów. Elity i instancje wtadzy w rejencji katowickiej w latach 1939-1945, Katowice 1998.

Kaliński J., Historia gospodarcza XIX i XX w., Warszawa 2008.

Keilig W., Das deutsche Heer 1939-1945. Gliederung, Einsatz, Stellenbesetzung, Bad Neuheim 1956.

Kobylarz R., Sznotala K., Wykaz niemieckich obozów jenieckich 1939-1945, Opole 2010.

Konečny Z., Mainuš F., Obozy jenieckie na Górnym Śląsku ( $Z$ dziejów stalagu cieszyńskiego), red. A. Szefer, Katowice 1969.

Konieczny A., Rozmiary zatrudniania zagranicznych robotników przymusowych i jeńców wojennych w gospodarce Dolnego Śląska w latach II wojny światowej, „Studia Śląskie” 1968 , t. 13, s. 235-288.

Krasuski J., Historia Niemiec, Wrocław-Warszawa-Kraków 2008.

Kujat J.A., Pieniądz zastępczy w obozach jenieckich na terenie rejencji wroctawskiej $w$ czasie I i II wojny światowej, „Łambinowicki Rocznik Muzealny“ 2000, t. 23, s. 7-26.

Lauerwald H., In fremdem Land. Kriegsgefangene im Stalag VIII A Görlitz (1939-1945). Tatsachen, Briefe, Dokumente, Görlitz 1996.

Lauerwald H., Primum viver. Zuerst leben. Wie Gefangenen des Stalags VIII A Görlitz erlebten. Dokumentation und Grundlage mündlicher und schriftlichen Quellen ehemaliger Kriegsgefangener aus Frankreich, Belgien und Italien, Bautzen 2008. 
Lemiesz W., Praca przymusowa jeńców wojennych w Niemczech w latach II wojny światowej, Zielona Góra 1969.

Levie H.S., The Employment of Prisoners of War, „American Journal of International Law” 1963 , vol. 57 , s. $318-353$.

Lusek J., Obozy jenieckie Teschen w latach II wojny światowej, Český Těšín 2015.

Lusek J., Wystawa „Praca przymusowa. Niemcy, pracownicy przymusowi i wojna” (Zwangsarbeit. Die Deutschen, die Zwangsarbeiter und der Krieg. Berlin), 27 września 2010 - 31 stycznia 2011, „Łambinowicki Rocznik Muzealny” 2011, t. 34, s. 177-184.

Lusek J., Goetze A., Stalag VIII A Görlitz. Historia - teraźniejszość - przysztość, „Łambinowicki Rocznik Muzealny” 2011, t. 34, s. 27-52.

Majewski R., VIII Okręg Wojskowy Wehrmachtu we Wroctawiu (1936-1945) (Studium historyczno-wojskowe), Wrocław 1991.

Masnyk M., Historia Górnego Ślaska. Polityka, gospodarka i kultura europejskiego regionu, Gliwice 2011.

Mattiello G., Vogt W., Deutsche Kriegsgefangenen- und Internierungseinrichtungen 19391945. Handbuch und Katalog. Lagergeschichte und Lagerzensurstempel, Bd. 1, Koblenz 1986.

Meyer A., Das Syndikat. Reichswerke „Hermann Göring”, Braunschweig 1986.

Norman Gibbs. Jeniec wojenny nr 16349. Dziennik retrospektywny, oprac. J. Lusek, Bytom 2018.

Obozy hitlerowskie na ziemiach polskich 1939-1945. Informator encyklopedyczny, red. Cz. Pilichowski i in., Warszawa 1979.

Obozy w Lamsdorf/Eambinowicach (1870-1946), red. E. Nowak, Opole 2006.

Próchnicki L., Z dziejów myśli ekonomicznej, Warszawa-Szczecin 2002.

Riedel M., Eisen und Koble für das Dritte Reich. Paul Pleigers Stellung in der NS-Wirtschaft, Göttingen-Frankfurt am Main-Zürich 1973.

Saath G., Die Industrie der angegliederten oberschlesischen Ostgebiete, Berlin-Prag-Wien 1942.

Sawczuk J., Hitlerowskie obozy jenieckie w Eambinowicach w latach 1939-1945, Opole 1974.

Senft S., Więcek H., Obozy jenieckie na obszarze Śląskiego Okręgu Wehrmachtu 1939-1945, Wrocław-Warszawa-Kraków-Gdańsk 1972.

Speckner H., In der Gewalt des Feindes. Kriegsgefangenenlager In der „Ostmark” 19391945, Wien-München 2003.

Spoerer M., Zwangsarbeit unter dem Hakenkreuz. Ausländische Zivilarbeiter, Kriegsgefangene und Häftlinge im Deutschen Reich und im besetzten Europa 1939-1945, Stuttgart 2001.

Stanek P., W niewoli niemieckiej. Informator wystawy statej Centralnego Muzeum Jeńców Wojennych w Eambinowicach-Opolu, Opole 2011. 
Stanek P., Terpińska-Greszczeszyn J., W cieniu „wielkiej ucieczki”. Kompleks obozów jenieckich Sagan (1939-1945), „Łambinowicki Rocznik Muzealny” 2011, t. 34, s. 125-141.

Sulik A., Przemyst ciężki rejencji katowickiej w gospodarce III Rzeszy (1939-1945), Katowice 1984.

Szpak J., Historia gospodarcza powszechna, Warszawa 2003.

Tessin G., Verbände und Truppen der deutschen Wehrmacht und Waffen SS im Zweiten Weltkrieg 1939-1945, Bd. 3, Frankfurt am Main 1974.

Wickiewicz A., Niewola $w$ brytyjskim mundurze. Stalag VIII B (344) Lamsdorf, Opole 2016.

Z lat wojny i okupacji 1939-1945, t. 7, red. M. Anusiewicz, L. Grot, Warszawa 1977.

Zieliński Z., Niemcy. Zarys dziejów, Katowice 2003.

Zwangsarbeit im Bergwerk. Der Arbeitseinsatz im Kohlenbergbau des Deutschen Reiches und der besetzten Gebiete im Ersten und Zweiten Weltkrieg, Bd. 1: Forschungen, Hrsg. K. Tenfelde, H.-Ch. Seidel, Essen 2005.

\section{Joanna Lusek}

\section{FORCED LABOR OF PRISONERS OF WAR IN BYTOM DURING WORLD WAR II}

Summary. During World War II Upper Silesia was to strengthen the German economic potential by maximizing the involvement of industrial infrastructure for the needs of military operations. The strategic location of Bytom in the region was determined by the possibility of a quick transformation of the existing production from socially useful for the needs of the war economy. This plan was implemented in the second half of the 1930s. Upper Silesia, as a center of heavy industry, was to compete with the Ruhr Area in North Rhine-Westphalia.

After the outbreak of World War II, Bytom became part of the Katowice poviat. Heavy industry plants located in and around the city (mines, steel mills and steel mills cooperating with them) were subordinated to the Bytom-Północ Mining Authority (Bergamt Beuthen-Nord), the Bytom-Południe Mining Authority (Bergamt Beuthen-Süd) and partially the Gliwice-Północ Mining Authority (Bergamt Gleiwitz-Nord).

The German authorities were looking for an effective way to implement the war production. The idea was to minimize investment and use cheap labor. This allowed for the continuity of production under the conditions of hostilities. In 1940, prisoners of concentration camps, civilian forced laborers and prisoners of war held in the stalags of Lamsdorf and Teschen were brought to industrial plants. Over a 2500 thousand working commandos belonged to the stalags, of which 29 were located in the municipal and land poviats of Bytom. Initially, they were British, French and Belgian prisoners of war. From 1942 they were joined by Soviet prisoners of war, and from 1944 by interned Italian soldiers. Difficulties on the eastern front and the need to reduce production in many plants in 1942-1943 caused a change in the production profile. Single plants started to be included in the armament's companies. In 1943, coal mining in Upper Silesia reached 100 million tons. In Bytom, as a result of over-exploitation of coal deposits 
directly outside the city, plans for deglomeration and resettlement of residents to the vicinity of Pyskowice appeared. Ultimately, they were not implemented. In January 1945, there were about 9600 thousand prisoners of war in the working commandos in industrial plants in Bytom and the surrounding area. In the death marches, on foot, they then went deeper into the Third Reich. The barracks were empty.

Keywords: Bytom, prisoners of war, Stalag VIII B i 318/VIII F Lamsdorf, Stalag VIII D, VIII B/Z, VIII B Teschen, forced labor, World War II 